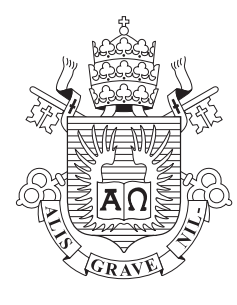

Pontifícia

UNIVERSIDADE

Católica

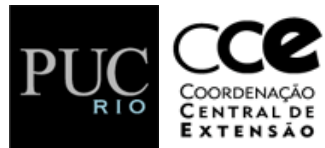

Evelyn Grumach

Reflexões sobre o Belo e o Sublime no Romantismo

Monografia apresentada no programa de Pós-graduação em História da PUC-Rio como requisito parcial para obtenção do titulo Especialista em História da Arte e Arquitetura no Brasil.

José Thomaz Brum

Orientador

Departamento de História - PUC-Rio

Rio de Janeiro, 25 de fevereiro de 2016 


\section{Evelyn Grumach}

\section{Reflexões sobre o Belo e o Sublime no Romantismo}

Monografia apresentada no programa de Pós-graduação em História da PUC-Rio como requisito parcial para obtenção do titulo Especialista em História da Arte e Arquitetura no Brasil.

José Thomaz Brum

Orientador

Departamento de História - PUC-Rio

Antonio Edmilson Martins Rodrigues

Departamento de História - PUC-Rio

Maria Eduarda Castro Magalhães Marques

Departamento de História - PUC-Rio

Rio de Janeiro, 25 de fevereiro de 2016 
@ Todos os direitos reservados. É proibida a reprodução total ou parcial do trabalho sem autorização do autor, do orientador e da universidade.

\section{Evelyn Grumach}

Graduada em Desenho Industrial e Comunicação Visual pela ESDI - Escola Superior de Desenho Industrial, UERJ, em 1973. Atua na área de Design Gráfico desde então, através de seu escritório eg.design. É professora do Departamento de Artes e Design na PUC-Rio, nas disciplinas de Projeto e Biônica. Orienta trabalhos de conclusão de curso e é consultora de Design Gráfico na Empresa-Júnior da Puc. 
À curiosidade que de tão instigante não nos deixa parar. 


\section{Agradecimentos}

Agradeço a meu orientador José Thomaz Brum que através de suas brilhantes aulas me apresentou ideias que se tornaram fundamentais para meu conhecimento e crescimento.

A PUC pela ajuda que me permitiu frequentar o curso e com isso possibilitar o acesso ao conhecimento.

Aos professores Antonio Edmilson Martins Rodrigues e Maria Eduarda Castro Magalhães Marques, agradeço o carinho que sempre recebi de ambos e por aceitar participar da comissão examinadora.

À minha família querida que compreendeu e aceitou os momentos de reclusão necessários para o sucesso do trabalho.

E para João de Souza Leite, meu carinho especial por todos os ensinamentos passados, pelo estímulo para ir em frente e pela enorme paciência ao ler e comentar meus escritos. 


\section{Resumo}

Grumach, Evelyn. Reflexões sobre o Belo e o Sublime no Romantismo. Rio de Janeiro, 2016. 50p. Monografia de Especialização Lato-Senso Departamento de História. Pontifícia Universidade Católica do Rio de Janeiro.

Este trabalho pretende examinar as categorias do Belo e do Sublime no período do Romantismo através de conceitos dos filósofos Edmund Burke e Immanuel Kant. Abordaremos também a questão do gosto e do juízo estético, fundamentais para compreender os paradigmas do período. Em apoio ao desenvolvimento da pesquisa, serão apresentados o pensamento dos filósofos Johann Gottlieb Fichte, Friedrich Schelling, Johann Wolfgang Von Goethe e Friedrich Schiller tão fundamentais para a compreensão do panorama da época. A pesquisa é complementada por obras de artistas que tiveram papel significativo na representação do Sublime no Romantismo.

O trabalho busca organizar, com os conceitos fundamentais do Belo e do Sublime, ferramentas para uma futura reflexão das manifestações da arte no moderno e no contemporâneo.

\section{Palavras-chave}

Filosofia; século XIX; Burke; Kant; arte; Romantismo; Classicismo; Belo; Sublime; gosto; juízo estético. 


\section{Abstract}

Grumach , Evelyn . Reflections on the Beautiful and the Sublime in

Romanticism . Rio de Janeiro , 2016. 50p . Specialization thesis Lato Senso Department of History . Pontifical Catholic University of Rio de Janeiro .

This paper aims to examine the categories of the Beautiful and the Sublime in European Romanticism through concepts and thoughts by philosophers Edmund Burke and Immanuel Kant. It also discusses the issues of taste and aesthetic judgment, an understanding key to the built paradigms of the period. In supporting the research development, it will also be presented some of the thinking of philosophers Johann Gottlieb Fichte, Friedrich Schelling, Johann Wolfgang von Goethe and Friedrich Schiller, so fundamental to understand the landscape of that time. The research is complemented by artists works who have played a significant role in Sublime representation in Romanticism. Grounded in concepts of the Beautiful and Sublime, the work seeks to organize tools for future consideration of art manifestation in modern and contemporary times.

\section{Keywords}

Philosophy; 19th Century; Art; Romanticism; Classicism; The Beautiful; The Sublime; Taste; Aesthetic Judgment; Romantic subject 


\section{Sumário}

1. Apresentação 12

2. Categorias estéticas 14

3. Sobre o gosto e a capacidade de julgar 19

3.1. O gosto em Burke 19

3.2. Kant e o juízo estético 22

3.3. O gosto em Kant 25

4. Sobre o Belo e o Sublime 28

4.1. O Belo e o Sublime em Burke 28

4.2. O Belo e o Sublime em Kant 33

5. O Romantismo 37

5.1. O contexto histórico 37

5.2. O movimento Sturm und Drang 39

5.3. A estética de Fichte, Schelling, Goethe e Schiller 41

5.4. O sujeito romântico 45

5.5. O panorama artístico: Neoclassicismo x Romantismo 47

6. Considerações Finais 56

$\begin{array}{lll}\text { 7. } & \text { Referências Bibliográficas } & 61\end{array}$ 


\section{Lista de imagens}

FIGURA 1 _Giovanni Battista Piranesi (1720-1778): Untitled etching (called "The Drawbridge"), plate VII (of 16) from the series The Imaginary Prisons (Le Carceri d'Invenzione), Rome, 1761 edition (reworked from 1745), Google Art Project

FIGURA 2 _Alexander Cozens (1717-1786), Close of the Day, Sunset on the Coast, between 1768 and 1775, Google Art Project

FIGURA 3_John William Waterhouse (1849-1917), Miranda, The Tempest, 1916, Google Art Project

FIGURA 4_Johann Heinrich Füssli (1741-1825), The nightmare/O pesadelo, 1781, Google Art Project

FIgURA 5_William Blake (1757-1827), imagem do Minotauro, Inferno de Dante, Canto XII,12-28, The Minotaur XII, Google Art Project

FIGURA 6_Caspar David Friedrich (1774-1840), Caminhante sobre o mar de névoa (c.1817) óleo sobre tela 98,4 x 74,8cm, Google Art Project

FIGURA 7_Giovanni Battista Piranesi (1720-1778) .The temple of Athena, 1777.

FIGURA 8_Honoré Daumier (1808-1879), Crispin and Scapin, 1858-60, Google Art Project

FIGURA 9_John Constable (1776-1837), Seascape Study with Rain c.1824

FIGURA 11_J. M. William Turner (1775-1851). Snow Storm, Steam-Boat off a Harbour's Mouth (1842), Google Art Project

FIGURA 10_Eugène Delacroix (1798-1863), Horse Frightened by a Storm, 1824, Google Art Project

FIGURA 12_Caspar David Friedrich (1774-1840), Der Mönch am Meer, Google Art Project 
“Um quadro verdadeiramente molhado, enlameado e alagado, capaz de perturbar um homem doente dos nervos.

Contudo, havia nele uma espécie de sublimidade indefinida, incompleta, inimaginável, que congelava sua atenção, até que involuntariamente você jurasse a si mesmo desvendar o significado daquela pintura extraordinária."

Herman Melville, Moby Dick 


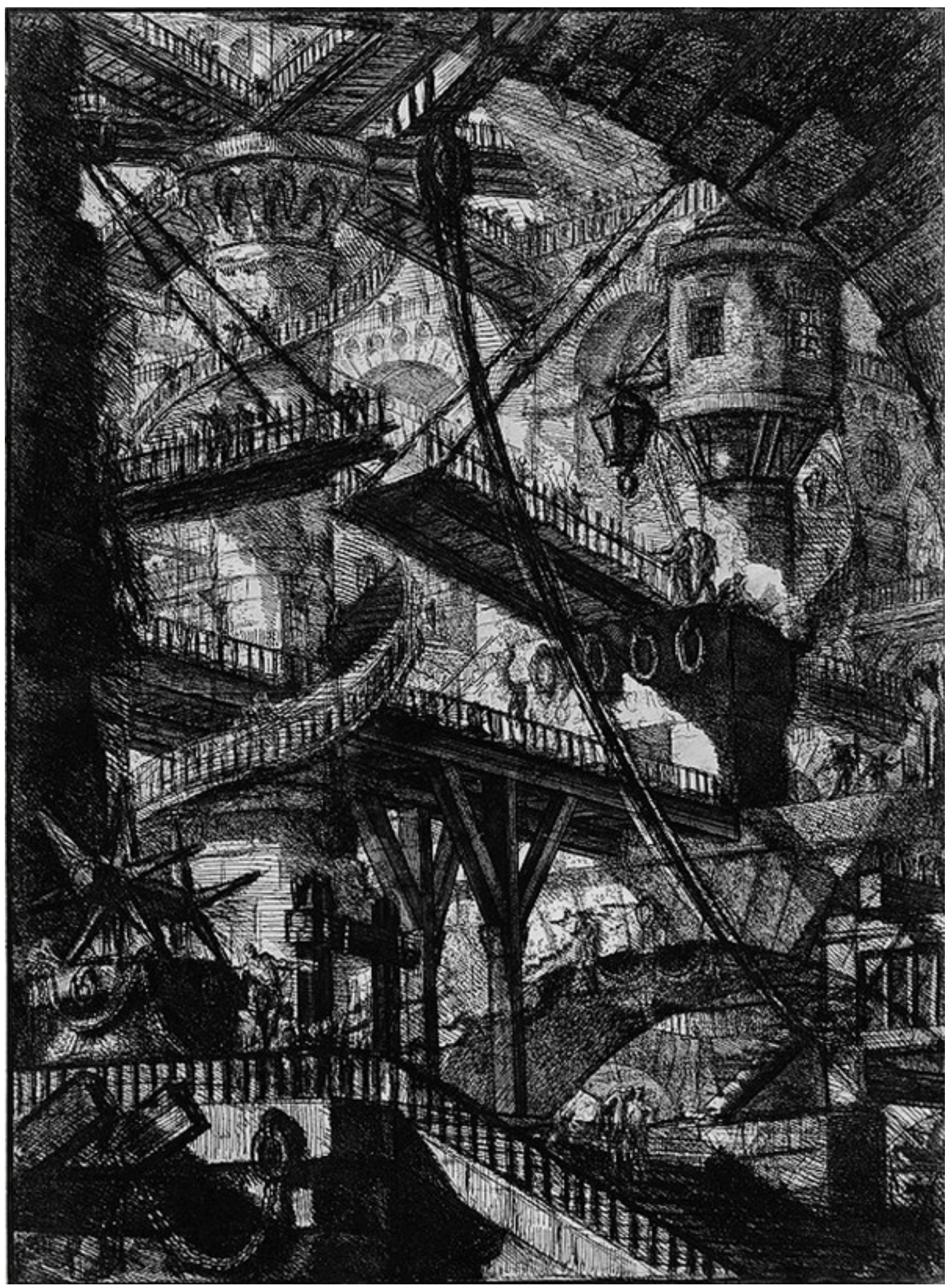

FIGURA 1 _ Giovanni Battista Piranesi: Untitled etching ("The Drawbridge"). 1761 


\section{Apresentação}

Quando afirmamos que alguma coisa é bela, estamos atribuindo um juízo à coisa, já que nada é Belo simplesmente por existir. Buscando compreender os conceitos de beleza que não fixasse cânones reducionistas, a filosofia nos forneceu instrumentos para uma investigação teórica, possibilitando a compreensão de seus possíveis significados e das relações entre o Belo e o Sublime, estabelecidas entre a obra e o espectador.

Diferentemente do Clássico utópico e universal, o Belo assume no Romantismo um caráter subjetivo e mutável, transmutando o "Belo objetivo" em "Belo subjetivo". Surge assim, no século XVIII uma filosofia moderna que propõe um sujeito que abre espaços para suas percepções mais obscuras. A noção de Sublime vem preencher esses espaços de imponderabilidade, de inacessibilidade perante forças desconhecidas, promovendo momentos de enlevação que exprimem estados emocionais particulares de extremo impacto.

Segundo Benedito Nunes, coube à vertente alemã o emprego da palavra "romântico" inserida em uma conotação critica e histórica. Ligada ao Classicismo de Weimar, quando Goethe e Schiller valorizavam padrões artísticos e estéticos da Grécia antiga; por um vinculo com a poesia ingênua dos antigos e pela poesia sentimental dos modernos, ascende uma geração 
posterior ao movimento Sturm und Drang paralelo ao idealismo kantiano. Suas matrizes filosóficas encontram-se também na metafísica do espírito de Fichte e na metafísica da natureza de Schelling.

O Sublime, como noção estética foi abordado por diversos pensadores ao longo da história: na antiguidade através o pensamento religioso de Longino e no ideal de Platão; com o sensualista Edmund Burke e no Sublime transcendental de Kant; no Romantismo histórico com Hegel e mais recentemente por Lyotard, que estabeleceu relações neste campo da estética na contemporaneidade.

O Sublime é a experiência do inexprimível. Com os Românticos, há um deslocamento da representação simbólica que ocorre quando o significado está no significante para o uso de alegorias como quebra desta harmonia. Ao gerar uma dissonância entre sua aparência e sua essência — predominantes na arte clássica, o Romantismo aponta para uma insuficiência na contemplação da aparência, que deixa de ser esteticamente suficiente para explicá-la.

Longino filósofo do século I a.C., em seu tratado "O Sublime", descreve como obter o mais elevado efeito na audiência através da oratória. Afirmava que o Sublime se dá "quando há muita matéria para reflexão [...] além do que dizem as palavras". ${ }^{1}$ A função e objetivo seriam despertar no espectador um estado de paixão e inspiração em busca um impacto que eleve a alma além do sensível.

A categoria estética do Sublime, tratada por Burke e Kant utiliza a alegoria como oposição à beleza. Assim, o Sublime avança e supera a bela aparência pois sua representação ultrapassa sua própria essência, conflituosa e em litígio com a imaginação. Ao fracassar na representação sensível que comporte idéias suprassensiveis, representa-se agora a própria inadequação da representação.

\footnotetext{
${ }^{1}$ apud Pedro Duarte, 2011: 136.
} 


\section{2}

\section{Categorias estéticas}

A antiguidade Clássica considerava a beleza como algo em si. Platão, em Hípias Maior ${ }^{1}$, através do diálogo entre Sócrates e Hípias, formula diversas hipóteses sobre o que seriam "as coisas belas" ao examinar as inúmeras possibilidades onde o Belo estaria aparente. Ao desconstruir os argumentos, Sócrates descreve o Belo como ideia, unindo o bem ao Belo numa coisa só e que estando fora do mundo sensível existiria somente no mundo das ideias, fora da realidade, portanto inatingível.

Até o Classicismo do século XVIII, a noção de Belo existia como o cerne da categoria estética. Para os gregos, o termo categoria - introduzido na filosofia por Aristóteles, designava as diferentes maneiras pelas quais se podia fazer uma afirmação e compreendia as categorias aléticas, que julgam o verdadeiro; as categorias éticas que julgam o bem e as estéticas, que julgam o Belo. Em 1892, em sua "Introdução à estética" Karl Gross, rejeita a estreita visão da disciplina que propõe o Belo como paradigma e incorpora outras noções relacionadas à beleza, como o Sublime, o Pitoresco e a Graça. O Belo passa a ser considerado como um valor entre os demais, uma categoria entre outras, possibilitando assim, um pluralismo estético.

\footnotetext{
${ }^{1}$ Platão: 1980.
} 
À Graça atribui-se a qualidade estética das formas em movimento. Destreza e leveza em harmonia, graciosidade. Os antigos vinculavam a beleza à Graça por não considerar possível a existência de algo gracioso sem harmonia, já que somente com a junção de suas partes estruturadas, em harmonia, comporiam uma unidade externa una, tal como vemos nas estátuas ou na arquitetura gregas.

A Graça, como conceito estético específico se dá com o Iluminismo e segundo o filósofo sensualista Edmund Burke (1729-1797), diz respeito à postura e ao movimento, contínuo e pausado, uma ausência de dificuldade, não havendo esforço nem ângulos bruscos sendo a categoria estética que rege a dança, a mímica, os gestos.

"Nessa desenvoltura, nessa harmonia, nessa delicadeza de atitude e de movimento" que consiste toda a magia da Graça e é o que se chama seunão-sei-quê, visível a quem quer que observe atentamente a Venus de Medicis, o Antinoo ou qualquer outra estátua reconhecidamente muito graciosa". ${ }^{2}$

Friedrich Schiller (1759-1805) em seu ensaio "Sobre Graça e Dignidade" discorre que a Graça seria o resultado de uma síntese consciente entre a beleza fixa - que não se altera, que deriva da necessidade de algo ser o que é (como as estátuas) - e a beleza em movimento, que por sua vez, seria resultante de uma tentativa de liberdade e não necessariamente bem sucedida. Para tanto exemplifica com a dança, onde sua construção espacial é feita por uma escolha voluntária, que pode ou não ser realizada como previsto. No movimento, a Graça pode ser construída a cada instante e cada movimento pode ou não destruir a beleza.

O Pitoresco que inicialmente designava algo próprio para ser pintado e também um efeito bem sucedido no quadro, não mais se reporta à realidade. A natureza não é mais retratada pela sua aparência, mas sim artificializada, destacando elementos como a rusticidade, a irregularidade e a variedade,

\footnotetext{
${ }^{2}$ Burke, 1993: 126.
} 
através da representação de velhas casas, do campo, ruínas da antiguidade e de árvores frondosas com aspecto secular. A arte não se parece mais com a realidade, passa a olhar para si mesma. 0 Pitoresco admite a artificialização da natureza, como nas obras de Claude Lorrain (1600-1682), onde a luz transfigura a obra e a perspectiva não obedece mais à uma composição geométrica, como na perspectiva clássica; ou na pintura de Alexander Cozens (1717-1786) onde claros e escuros representam sensações visuais.

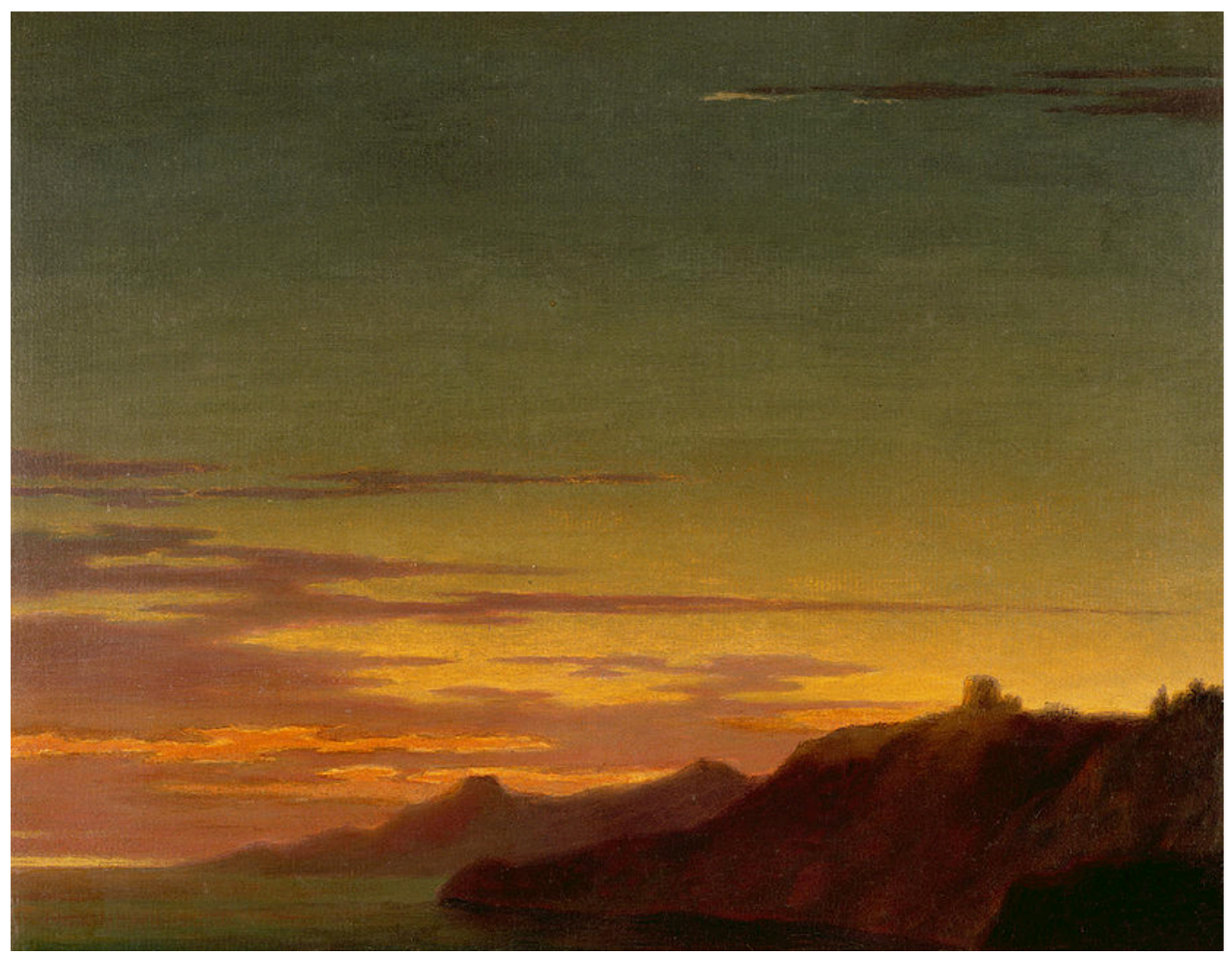

FIGURA 3_Alexander Cozens, Close of the Day-Sunset on the Coast , 1768 - 1775

O Pitoresco busca não mais a universalidade do Belo, mas o particular do característico e, que segundo Giulio Carlo Argan (1909-1992), "não se capta com a contemplação e, sim com a argúcia (wit) ou a presteza da mente, que permite associar ou "combinar" ideias-imagens, mesmo muito diversas e distantes. (...) A poética do "Pitoresco" medeia a passagem da sensação ao sentimento: é exatamente nesse processo do físico ao moral que o artista- 
educador é guia dos seus contemporâneos" ${ }^{3}$. É reflexiva ao colocar o homem perante a imensidão da natureza e de suas forças, mas de forma integrada em seu ambiente natural.

A categoria do Sublime - momentos de enlevação que exprimem estados emocionais particulares de extremo impacto - por sua vez revela uma imponderabilidade, uma inacessibilidade perante forças desconhecidas. O Sublime, como noção estética foi abordada por diversos pensadores ao longo da história: na antiguidade com o pensamento religioso de Longino e no ideal de Platão; no romantismo histórico com Hegel e com o Sublime transcendental de Kant.

A categoria do Sublime foi definida por Burke simultaneamente ao pintor Alexander Cozens (1717-1786) que definiu o Pitoresco. As duas categorias relacionam o humano e a natureza, porém em dimensões diferentes. A pintura pitoresca expressava-se na jardinagem, em uma educação contida sem perda de expressividade onde o indivíduo está integrado em seu ambiente natural. O Sublime é visionário, coloca o indivíduo diante das imensas forças da natureza quando experimenta sua pequenez, uma discórdia e uma angustia de solidão e impotência.

Argan argumenta que ambas as poéticas, tanto o Pitoresco quanto o Sublime, se completam e que "na sua contradição dialética refletem o grande problema da época, a dificuldade da relação entre indivíduo e coletividade". ${ }^{4}$

O Belo Clássico e Neo-Clássico - representação suprema de equilíbrio e harmonia - perde na modernidade seu caráter exemplar e paradigmático. Algo "apenas" Belo, segundo um gosto dominante, torna-se restritivo e pode ser denegrido.

Os modelos da beleza Clássica - a escultura, a arquitetura e a poesia dos gregos; o quattrocento renascentista e o neo-classicismo francês passam a ceder espaço para expressões como o Gótico, até então considerada até então uma manifestação bárbara. Com o Romantismo, surgem ainda novas categorias que se opõem ao Belo Clássico, como o maravilhoso e o

\footnotetext{
${ }^{3}$ Argan, 1998: 18.

4 Idem: 20.
} 
interessante, já que uma obra de arte não necessita ser bela e sim estimular o intelecto e surpreender. É neste período que alguns artistas vão buscar em suas lendas um espírito de resgate de origens.

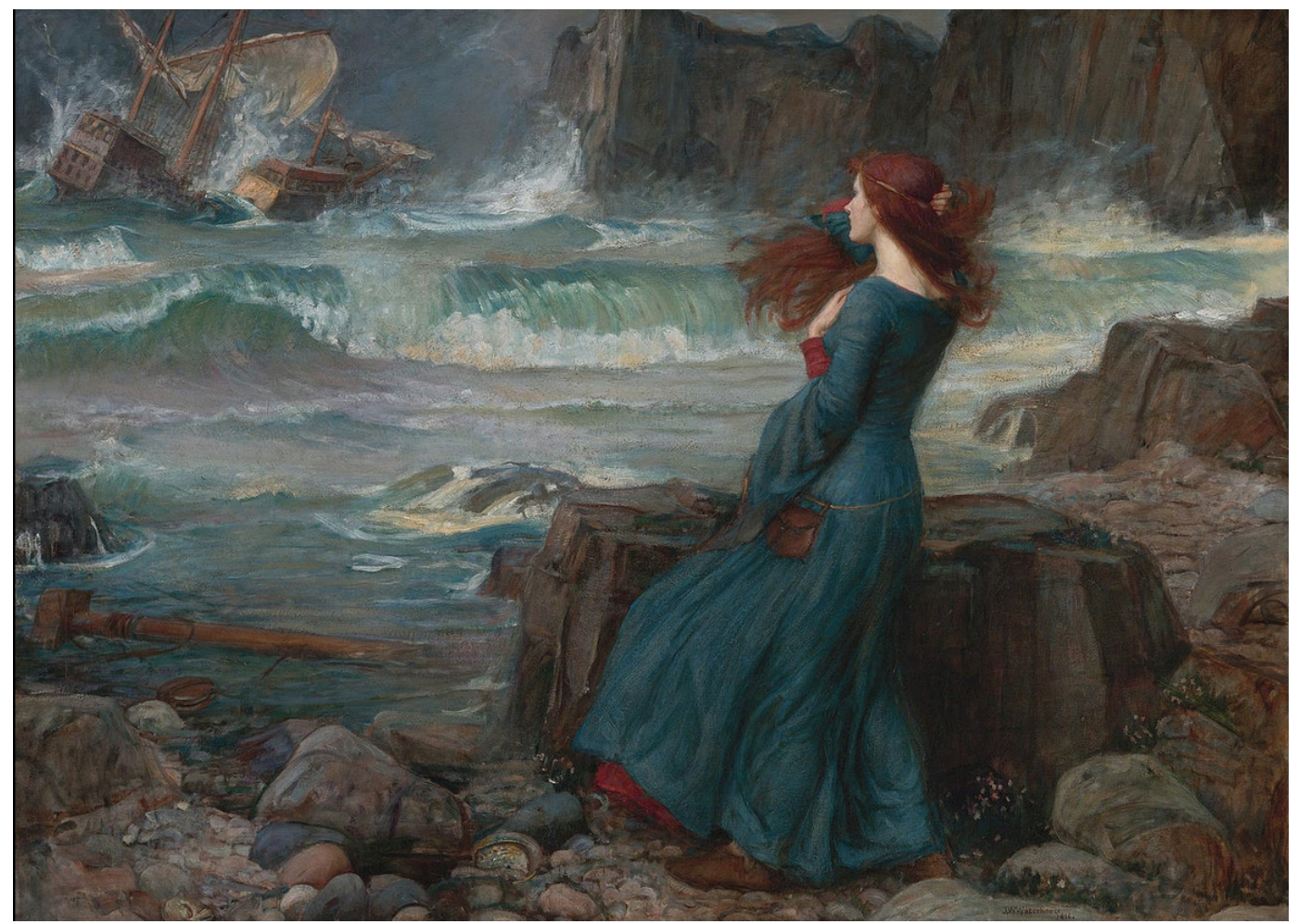

FIGURA 3_John William Waterhouse (1849-1917), Miranda, The Tempest, 1916 


\section{Sobre o gosto e a capacidade de julgar}

\section{1 gosto em Burke}

Couberam aos filósofos ingleses do século XVIII a introdução da noção de gosto (taste), introduzindo uma reflexão sobre o Belo e de como percebêlo. Locke (1632-1704), Berkeley (1685-1753) e Hume (1711-1776) afirmavam que a beleza habita em nós como sentimento inato e que essa sensação (feeling) vivenciada é aquela que forma os valores estéticos. Sendo sensualistas e portanto empiristas, esses filósofos consideraram que seria através das sensações que se atingiria o conhecimento e que este se configuraria de forma subjetiva. A beleza portanto estaria em nós como sentimento sendo possível admirar o Belo aonde quer que ele esteja, na forma em que se apresenta no mundo. A subjetividade vinculada ao sentimento afirmaria então o gosto como contingente, particular e arbitrário.

O ensaísta Edmund Burke (172901797) inicia sua investigação sobre o gosto compreendendo-o inicialmente como "nada além daquelas faculdades do espírito que são afetadas pelas obras da imaginação das belas artes, ou que as julgam"1 - e procura investigar quais os princípios, quais os padrões da razão e do gosto que seriam comuns aos indivíduos e que portanto afeta-

\footnotetext{
${ }^{1}$ Burke, 1993: 23.
} 
riam a imaginação. Em seu ensaio, examina as três faculdades inatas do homem que se relacionam com os objetos exteriores: os sentidos, a imaginação e o juízo.

Por "sentidos" supõe que, sendo os órgãos humanos comuns a todos, suas sensações e maneiras de perceber o mundo exterior também o são. Admite também que os homens são guiados por diferenças, mas que estas não anulam o princípio do sentido comum. Cita como exemplo, a aceitação comum das sensações de quente e frio; de duro ou mole; azedo ou doce; luz e escuridão.

\footnotetext{
“Assim, o prazer de todos os sentidos, da visão e inclusive o do gosto, o mais incerto deles, é o mesmo para todos os homens, os de elevada ou de baixa categoria social, doutos ou ignorantes." 2
}

Outra faculdade criativa própria do homem é a faculdade da imaginação, responsável pela fantasia e pela invenção. É a maneira com a qual o homem organiza e combina as imagens das coisas recebidas e de como é capaz de variar esta disposição pelos sentidos, sem ser capaz no entanto, de produzir algo totalmente novo. A imaginação, para Burke, seria somente o representante dos sentidos. 0 gosto critico, o juízo, aquele que se afirma na opinião, não depende de algo superior pertencente ao humano e sim à sua capacidade de ter um conhecimento maior ou menor sobre o assunto. Reafirma assim que o que há de natural no gosto seria praticamente comum a todos os homens.

No entanto, aponta o fator "grau" para demonstrar que uma sensibilidade inata maior ou mais atenta e prolongada sobre um objeto, pode promover diferenças na observação e com essa divergência aplica o conceito de juízo, que é um aperfeiçoamento obtido pela atenção e pelo hábito de raciocinar. Ao examinar o gosto somente pela sua natureza, os princípios se assemelham, mas a prioridade dada pelos indivíduos varia enormemente, já que as qualidades do gosto - sensibilidade e juízo - variam entre as pessoas.

${ }^{2}$ Burke, 1993: 26 
Assim, o que é chamado de gosto, seria na verdade um juízo mais aperfeiçoado.

A diferença resultante entre os gostos, para Burke, revela somente que não há resposta precisa quanto ao prazer ou dor que um homem particular pode encontrar no gosto de uma determinada coisa e que seria necessário conhecer seus hábitos e suas predisposições para contextualizá-lo e emitir conclusões. Todos os homens conservam em suas memórias as vivências das causa naturais e originais que foram fontes de prazer ou dor. Podem com elas reportar as coisas dos sentidos e conformar suas novas sensações e opiniões.

“Em suma, parece-me que o denominado gosto, na sua acepção mais geral, não é uma idéia simples, e sim algo composto em parte de uma percepção dos prazeres primários dos sentidos e dos prazeres secundários da imaginação, e em parte dos veredictos da faculdade do juízo, no que concerne às várias relações dessas duas espécies de prazeres e no que diz respeito às paixões humanas, aos costumes e às ações dos homens. São esses os elementos constituintes do gosto e o fundamento de todos eles é o mesmo no espírito humano, pois como os sentidos são as grandes fontes de nossas idéias e, por conseguinte de todos os nossos prazeres, quando eles não são vagos e arbitrários, a base inteira do gosto é comum a todos os homens e, portanto existe um fundamento sólido para um raciocínio irrefutável sobre essas questões."3

A falta de gosto, segundo Burke seria a falta de sensibilidade e um defeito do juízo que gera o gosto equivocado ou mau gosto. A ignorância, o preconceito, a leviandade, citando algumas das paixões e vícios que adulteram o juízo, são as causas das diferentes opiniões acerca do objeto de entendimento e conclui que os homens divergem menos quanto as questões de gosto do que das questões que dependem da razão pura.

Burke afirma ainda que uma obra de arte julgada de bom gosto parte inicialmente de uma avaliação da sensibilidade, pois pede acesso aos

\footnotetext{
${ }^{3}$ Burke, 1993: 31 .
} 
prazeres da imaginação. Somente aqueles que são a ela sensíveis terão sobre a obra o conhecimento e o juízo adequado sobre elas. A sensibilidade, no entanto pode variar e, um observador menos informado poderá ver e permitir uma descoberta mais extraordinária, grandiosa já que, menos atento aos defeitos poderá obter da experiência prazeres mais autênticos, menos submetidos à razão.

Conclui em seu texto, que o gosto e o juízo são aperfeiçoados pela ampliação do conhecimento. Com isso diverge dos que afirmam ser o gosto uma faculdade do espírito independente e distinta do juízo e da imaginação, uma espécie de instinto que nos afeta de modo natural. ${ }^{4}$

\subsection{Kant e o juízo estético ${ }^{5}$}

Foi com o filósofo alemão Immanuel Kant (1724-1804) que o conceito de gosto foi deslocado de um sentimento para um juízo, ao examinar a oposição existente entre o racionalismo e o empirismo e introduzindo uma nova filosofia do sujeito.

Para os racionalistas é no intelecto que estão presentes nossos valores e pensamentos, priorizando a razão como caminho para a verdade, enquanto para os empiristas, a experiência de acesso ao conhecimento se dá através do mundo sensível. Kant propõe um sujeito transcendental que vivencia sua relação com o mundo através de um entendimento sem utilidade, sem finalidade subjetiva com o bem, mas uma finalidade em si, autônoma. Visa a união dos sentimentos estéticos a uma faculdade transcendental do espírito humano, a "faculdade de julgar em relação ao sentimento de prazer e de dor".

\footnotetext{
${ }^{4}$ Idem: 36. Na nota 15, referindo-se provavelmente a noção de sentido interno ou sexto-sentido.

${ }^{5}$ É na terceira crítica, última das três escritas pelo filósofo Immanuel Kant, que é apresentado o conceito de juízo estético. Apesar de Kant discorrer sobre o sublime, sobre o gênio e consequentemente sobre as Belas Artes, não se pode dizer que formulou uma teoria estética já que o juízo estético é reflexionante, portanto subjetivo. Embora não chegue a formular uma teoria estética, funda as bases da teoria de Hegel, apresentada poucos anos depois.

https://pt.wikipedia.org/wiki/Critica_do_Julgamento, acesso em 05-12-12015
} 
Em sua "Critica da razão pura" (1781) Kant discorre sobre os limites daquilo que se pode conhecer, através daquilo que não se pode. Apresenta uma estética transcendental, onde relaciona tempo e espaço para formular como as coisas aparecem para nós. As coisas em si, as coisas como aparecem para nós, segundo Kant, nos chegam através de três faculdades: a sensibilidade, que sendo passiva, recebe os dados desordenados das sensações empíricas; a imaginação, mediadora e não perceptível, que procura ordenar e dar formas a essas sensações indefinidas e indeterminadas e o entendimento que constrói um conceito ativo, uma forma final. Para Kant, estes 3 componentes vão compor o cenário das atividades a priori, fundamentadas na não experiência, "um lugar com condições de possibilidades de". Uma condição transcendental, já que o homem, para Kant, não experimenta sensações que não seja em um espaço e tempo, seja um conhecimento simples até as teorias mais complexas.

Ao examinar a coisa, tal qual ela aparece para nós, Kant chama a atenção para a existência do fenômeno; ou seja, distingue o conhecimento a priori do objeto ou do fato porém é "fenômeno", aquilo que visualizamos. Ser é ser percebido. Ser é ser fenômeno.

Este processo transcendental, que parte da sensação para atingir o conceito, se dá na mesma maneira no juízo estético. Investigando sobre o belo, Kant aponta para o poder de julgar, pertencente a todos indivíduos. Kant nos coloca frente a um jogo livre onde a forma e o entendimento são vivenciadas por um sentimento de prazer totalmente desvinculados de necessidades, sem determinação de um conceito pois, ao determiná-lo estaremos no valor do conhecimento e não do estético. O prazer estético, para Kant é o puro prazer da forma e está relacionado ao prazer ou desprazer que o objeto nos desperta, "é o que agrada universalmente, sem relação com qualquer conceito". 6

“ (...) A diferença entre uma representação clara e uma representação obscura é apenas lógica e não se refere ao conteúdo. (...) a

\footnotetext{
${ }^{6}$ https://pt.wikipedia.org/wiki//mmanuel_Kant, acesso em 6/12/20154
} 
representação de um corpo na intuição nada contém que possa pertencer a um objeto em si; é somente o fenômeno de alguma coisa e a maneira segundo a qual somos por ela afetados; e essa receptividade da nossa capacidade de conhecimento se denomina-se sensibilidade e será sempre totalmente distinta do conhecimento do objeto em si mesmo, mesmo que se pudesse penetrar até ao fundo do próprio fenômeno." 7

Kant enuncia sua primeira reflexão sobre o sublime em um texto de 1764, "Observações sobre o sentimento do belo e do sublime", mas será somente na sua "Critica da faculdade do juízo" em 1790 que irá aprofundar este tema, abandonando uma visão inicial próxima de Burke, que evidenciava a relação do sublime com os fenômenos da natureza e, que se contrapõem ao sereno prazer obtido com o belo contra o possível terror do sublime. Neste texto, Kant investiga os limites daquilo que seria nossa faculdade de julgar, considerando a razão, os sentimentos e a memória.

Kant distingue no juízo estético dois comportamentos: o juízo puro, que julga o belo e o sublime e o juízo empírico, que julga o agradável. Esta diferença o faz romper com os sensualistas, quando afirma que apesar do belo iniciar na sensação, seu âmago é transcendental, já que o sujeito se volta ao seu próprio espírito. Diz respeito ao estado do sujeito e não à natureza do objeto.

Apesar de não ser um sensualista, para Kant a sensação é o início do conhecimento. Não analisa as características do objeto belo, não as descreve, tampouco enuncia regras de como produzi-lo. Sua análise se dá no ato de consciência que julga o que é belo e nas condições que existem no intelecto para este reconhecimento. A base de sua concepção de conhecimento é encontrada na relação entre a representação e a realidade (conceito e intuição) que acionam o reconhecimento.

O juízo estético não se indaga sobre como são as coisas - competência do juízo de conhecimento e sim, se elas agradam ou não julgando o belo pelo

\footnotetext{
${ }^{7}$ Kant, 1974: 79 .
} 
prazer despertado individualmente, subjetivamente, sem valor moral ou conhecimento. No entanto, o juízo estético e o juízo de gosto exprimem também um prazer que sentimos em nos perceber representados no objeto, já que seria no prazer estético que se dá o entendimento.

É através da faculdade de julgar que o juízo estético ocorre, intermediando o conhecer e o desejar. Não saber o que a coisa é ou questionar o seu fim, sua utilidade ou se agrada ou não. 0 agradável apraz aos sentidos na representação de um objeto, portanto sujeito a interesses. Quando a faculdade de desejar é racional, ela busca o bem em si e manifesta-se como um juízo moral sobre o bem. 0 "bem em si" é um interesse forjado por uma vontade racional que tem na sua base uma idéia abstrata e conceitual. 0 bem é um juízo interessado.

\subsection{O gosto em Kant ${ }^{8}$}

No cenário anterior a Kant havia uma oposição entre a ideia de gosto, subjetivo, ligado ao arbítrio, contingente e particular, em contraste com o gosto universal e racional. Kant supera esta antinomia entre subjetivo e objetivo propondo em sua "Critica da Faculdade do Juízo", em 1790, uma nova teoria do gosto. Uma reflexão de como o gosto se manifesta entre a sensação e um julgamento e que ao experimentar uma experiência estética, o sujeito estaria sentindo reflexivamente, opinando, elaborando um julgamento, que para Kant seria a auto reflexão, uma ação transcendental.

O gosto, para Kant é a faculdade que julga o Belo, é a faculdade de julgar vinda do sentimento e não do intelecto, em uma representação dada universalmente, comunicável, sem intervenção de conceitos que identifique o que é a coisa observada. Não é somente um julgamento de sentimentos, mas também o sentimento de julgar. Ao se afirmar "isto é Belo" a partir de um sentir, é também o sentimento de estar julgando. 0 gosto, portanto seria um

\footnotetext{
${ }^{8}$ Em apontamentos das aulas proferidas por José Thomas Brum em 2007-1 e 2013-2 no curso de especialização em História da Arte e Arquitetura da PUC-Rio.
} 
juízo reflexivo, que inclui a universalidade do racionalismo e a afetividade do empirismo, duas dimensões antes separadas.

0 juízo do gosto é estético, já que para distinguir se algo é Belo, o fazemos pela sua representação e não pelo entendimento em vista do conhecimento. 0 prazer estético kantiano se dá ao se sentir o mundo no registro do “agradar" ou "não agradar". Não pertencendo ao conhecimento, o gosto não é lógico e sim estético e subjetivo, demonstrando como o sujeito pode por ele ser afetado.

Entre conhecer e desejar estaria o prazer da alma, cuja afetividade se manifesta sem lugar para um querer ou um fim; um sentir contemplativo que se dá no nível transcendental, ou a priori. A sensibilidade (sensação), a imaginação (forma) e o entendimento (o que singulariza) são as bases que movimentam a harmonia de entendimento. 0 prazer estético é a fruição contemplativa do mundo, sem querer conhecê-lo, nem moralmente, nem sensualmente. É um sentimento subjetivo que se dá sem nenhum conhecimento, sem apropriação do objeto. 0 Belo não é um objetivo de uma ação, não inspira nenhum desejo e, diante dele somos desinteressados. É uma experiência perceptiva. Isto é Belo porque assim o sinto, transcendentalmente, em mim.

Para compreender o gosto, Kant aplica o conceito de "complacência", associada à maneira como ajuizamos a simples contemplação e em como nos relacionamos com sua representação e não com a função ou critica sobre este objeto. E afirma que "cada um tem que reconhecer que aquele juízo sobre beleza, ao qual mescla o mínimo interesse é muito faccioso e não é nenhum juízo de gosto puro." 9

Um juízo de gosto pretende a ideia de um "sentimento comum" que é distinto do "senso comum" pois não se julga segundo conceitos e sim por sentimentos, livres de sentidos externos. O sentimento do Belo existe, a priori, independente da experiência.

\footnotetext{
${ }^{9}$ Kant, "Critica da Faculdade do juízo", in Duarte, 2013.
} 
Para Kant, o objeto se torna estético quando o homem une o seu agrado a uma harmonia subjetiva interna, concordante quando Belo, contrastante quando Sublime. 
É verdade que a natureza está escrita em caracteres legíveis, mas eles não são simples o bastante para permitir uma leitura corrente.

Edmund Burke ${ }^{1}$

\section{Sobre o Belo e o Sublime}

\subsection{O Belo e o Sublime em Burke}

No prefácio da primeira edição da sua obra “Uma investigação filosófica sobre a origem de nossas ideias sobre o Sublime e o Belo" Edmund Burke (1729-1797 $)^{2}$, discorre sobre os conceitos do Sublime e do Belo através de "uma pesquisa cuidadosa sobre as propriedades das coisas capazes, segundo nos mostra a experiência, de afetar o corpo e, portanto, de incitar nossas paixões" e com isso aplicar suas regras às artes de imitação.

Para analisar assuntos complexos e elucidar os freqüentes equívocos quanto as noções do Sublime e do Belo, descreve no prefácio da segunda edição, que esta pesquisa se dará através do método de abordagem que particulariza elementos distintos, examinando-os separadamente e reduzindo-os a maior simplicidade, propondo em seguida o exame de sua composição e seus princípios. Maiores serão as possibilidades de conhecimento quanto mais fundadas em induções mais amplias e completas, incorporando inclusive comparações de natureza análoga ou contrastantes. Sendo uma teoria apoiada na experiência e não na suposição ${ }^{3}$ seria, segundo Burke, uma

\footnotetext{
${ }^{1}$ Burke, 1993.

${ }^{2}$ idem, Prefácio à segunda edição

3 ibid: 14
} 
maneira de incluir o desconhecido e incorporá-lo, tornando-nos modestos perante o conhecimento.

Burke propõe em sua investigação acerca do Belo e do Sublime, buscar as origens dessas ideias esperando que se reconheça, independente de suas classificações, que "as qualidades colocadas em categorias distintas são, na realidade, de naturezas diferentes". ${ }^{4}$

Ao introduzir o Sublime no âmbito da metafísica cartesiana - filosofia moderna que introduz o sujeito, Burke aponta que na cisão entre o sujeito e o ser cria-se um novo sujeito, moderno, que opõe as ideias claras e distintas e às percepções obscuras, fazendo surgir uma estética de "sensibilidade obscura".

Sendo um filósofo sensualista, traz para o corpo a experiência estética: prazer e dor, sensações distintas que agora são reunidas em um prazer ambíguo, o delight, espécie de horror delicioso. O Sublime de Burke demanda o envolvimento do expectador, uma relação de equivalência entre a tensão propiciada e a paixão. A perda, a dor, a morte sendo despertadas por situações reais ou representadas com extrema realidade impedem o raciocínio e procuram alivio. ${ }^{5}$

Por não mais buscar a completude do ser, o Sublime de Burke é um "sentimento negativo" e se relaciona com os sentimentos de preservação do indivíduo. Dor, perigo, terror causam emoções mais fortes - mesmo sem que o sujeito esteja fisicamente expostos a eles - que o espírito é capaz de suportar. Trevas, vazio, solidão, insignificância. A atenuação desses sentimentos se dá pelo delight, a dor atenuada por um prazer de senti-la, transformando esta experiência na experiência estética do Sublime.

Beleza, para Burke é a qualidade dos corpos responsáveis por despertar amor ou sentimentos a ele relacionados. Uma qualidade puramente sensível das coisas distintas de outros atributos que distraiam a atenção para considerações secundárias. Distingue o amor como um contentamento do espírito que contempla algo Belo independente de sua natureza, do desejo ou

\footnotetext{
${ }^{4}$ lbid.

${ }^{5}$ Márcio Selligman Silva, apud Rossetti, 2014: 27.
} 
da luxuria - "um ardor do espírito que nos impele à posse de certos objetos que nos impressionam, não por serem Belos, mas por motivos completamente diversos" ${ }^{6}$

Não sendo um produto da nossa razão, e sim de uma impressão e sem conotação utilitária, a beleza consistiria em alguma qualidade dos corpos que age mecanicamente sobre o espírito humano, mediante a intervenção dos sentidos.

Em seu ensaio, Burke examina minuciosamente características físicas dos objetos que seriam, para ele as formas que definem o que é Belo do que é Sublime. Cabe ao Belo os pequenos objetos, a lisura das superfícies, a delicadeza de suas formas e a variação de suas partes. Deve ter uma estrutura delicada, de cores puras e luminosas. Os objetos do Sublime são de grande dimensões, ásperos e rústicos, são obscuros em direção às trevas, sólidos e de grandes massas. Conclui que, apesar de ideias de natureza tão diferentes, uma fundada na dor, a outra no prazer, podem estar juntas no mesmo fato, sem contudo perder suas características distintas.

O Belo, é o prazer positivo que relaxa os músculos e o corpo, que tem o gosto como juiz. O Sublime tenciona, promove um horror aliviado, é a estética da comoção.

Do Belo emana o instinto social, cabendo ao Sublime o instinto de conservação, já que sendo uma experiência estética de morte, transfere a ênfase do objeto para o sujeito que se reconhece como efêmero e moral e que lida com os limites da razão.

${ }^{6}$ Burke, 1993: 99. 


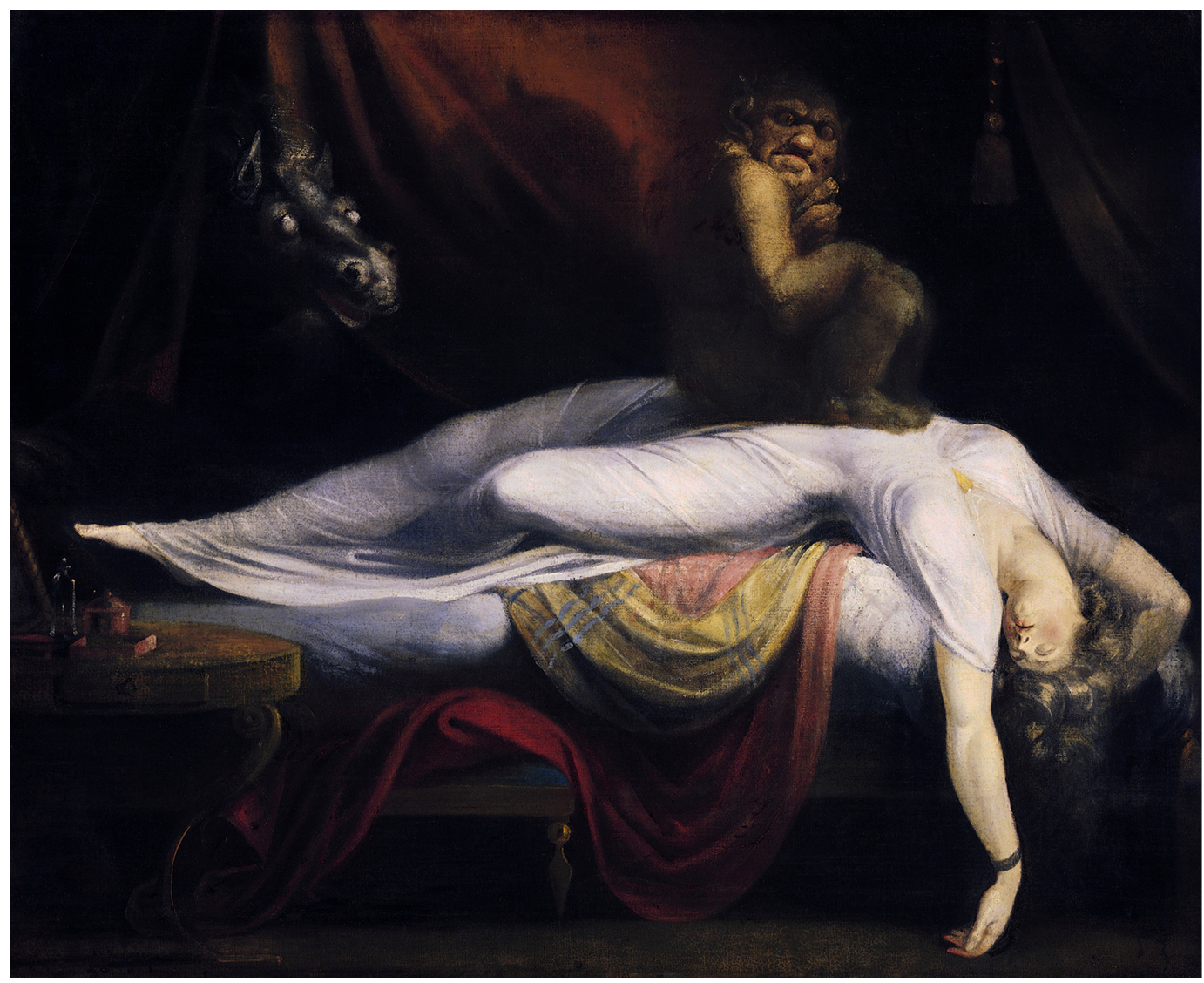

FIGURA 4_Johann Heinrich Füssli, The nightmare/O pesadelo, 1781

Encontramos na pintura de Johann Heinrich Füssli (1741-1825) a influência dos princípios estéticos de Burke descritos em seu tratado Enquiring into the Sublime and the Beautiful, ("Uma investigação filosófica sobre a origem de nossas ideias do Sublime e do Belo"), de 1786. Sua pintura emocional transmite uma percepção angustiante, de um mundo agressivo e povoado de figuras espectrais atormentadoras, agindo como vozes da consciência. Para Füssli, a arte é uma atividade espiritual, não naturalista. O Sublime não é transcendental, está no pesadelo, nas profundezas. É passional. Transmite um mundo povoado de figuras espectrais diluídas na meia-luz, sugerindo a opressão da obscuridade.

Tanto em Füssli como em William Blake (1757-1827), o mundo Clássico somente pode ser evocado como um espectro do passado. Contestam o espírito científico, mesmo reconhecendo o papel da ciência no eixo de uma nova cultura. 


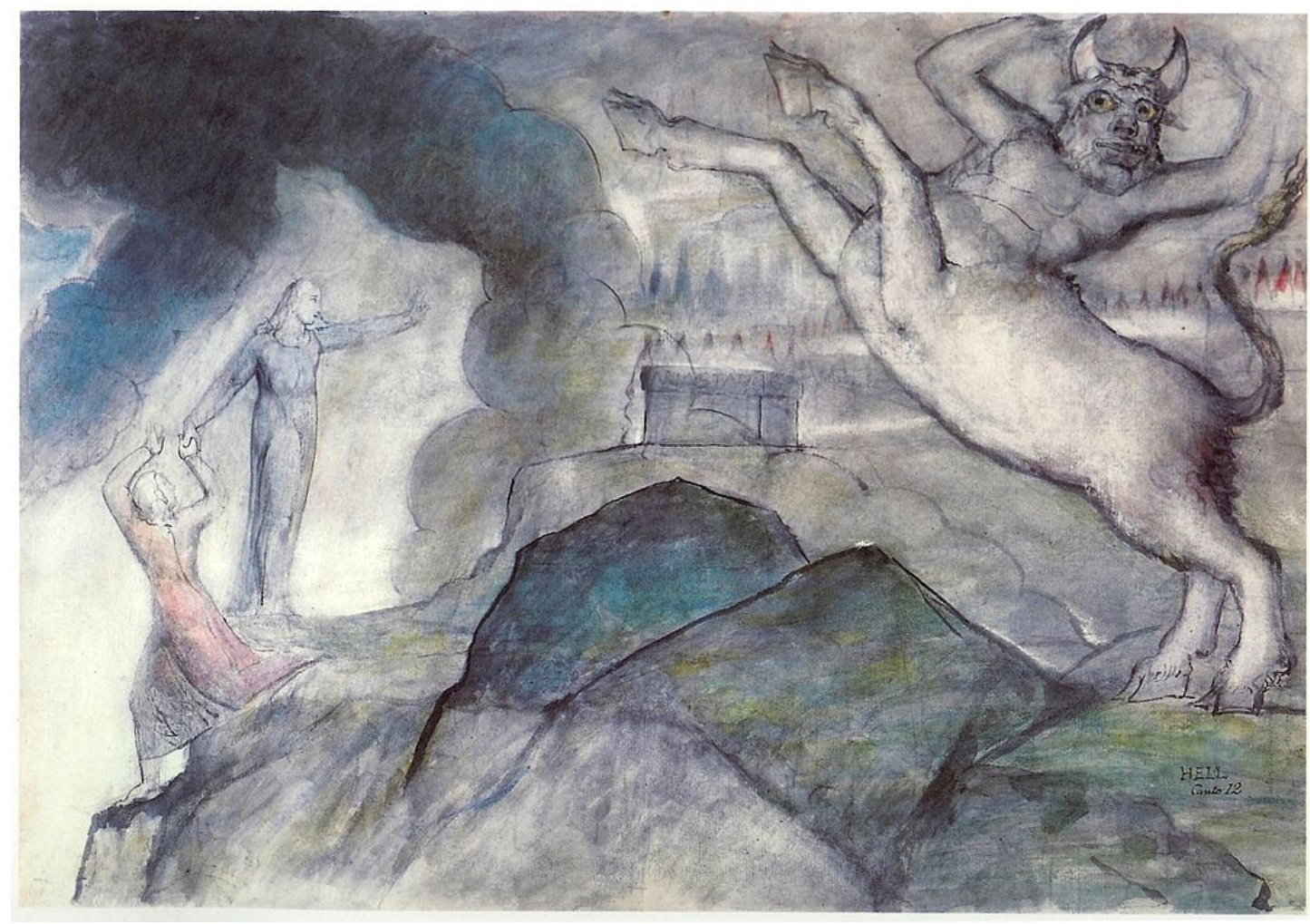

FIGURA 5_William Blake, imagem do Minotauro, Inferno de Dante

O poeta e pintor inglês William Blake (1757-1827), considerava a arte como sendo um conhecimento centrado não mais no indivíduo, mas em forças eternas e sobre-humanas, criando relações do ser com sua totalidade (natureza, mito, história, passado, presente, futuro). A Arte para Blake é um conhecimento intuitivo, não das coisas individuais, mas das forças eternas e sobre-humanas da criação. É a negação da ciência, é inspiração e não pesquisa, é subjetividade e não objetividade. O Sublime é visto como um esforço heróico, fadado ao fracasso. 


\subsection{O Belo e o Sublime em Kant}

Para Kant, o Belo e o Sublime possuem características comuns. Sendo juízos estéticos, desinteressados, sem objetividade e sem fim sensível ou moral, não estimulam nossos sentidos a agir em busca de um fim. 0 Belo e o Sublime por não serem mediados por conceitos nem subjugados a um entendimento, têm o alcance imediato do espírito. São conceitos opostos ao "bem em si", ao "agradável" já que ambos almejam e desejam algo.

A Analítica do Sublime, sendo um juízo estético-reflexivo permite avaliar aspectos semelhantes e aqueles que o separam do Belo, já que se utilizam do mesmo método aplicados no juízo do gosto. A complacência no Sublime, tanto quanto no Belo, deve ser segundo a qualidade, sem interesse; segundo a quantidade, de modo universalmente válido; segundo a relação, uma conformidade a fins subjetiva; e segundo a modalidade, como necessária. ${ }^{7}$

Para Kant, o que distingue o Belo do Sublime é a finalidade. O Belo convém às nossas faculdades e agrada por si. É uma experiência de harmonia e o objeto do Belo é seu símbolo. 0 Belo é forma, limite e suporta o ornamento. O Sublime, por sua vez está fora dos limites de compreensão; pode ser visto como algo esmagador, perturbador e faz disso sua finalidade estética. Não é uma característica do objeto, mas do sentimento humano que se reflete no objeto. É Belo o dia, encanta é Sublime a noite, assusta. É Belo o passado, controlado e já vivido; é Sublime o futuro, distante e desconhecido.

Kant distingue dois tipos de Sublime. O Sublime matemático - envolve o fenômeno de magnitude. É o absolutamente grande, ilimitado e que nos ultrapassa em sua extensão. O Sublime dinâmico - que nos ultrapassa em força e poder.

O Sublime matemático, da ordem da grandeza dos eventos da natureza, lembra à razão sua incapacidade harmonizar os sentidos, promovendo um descompasso entre o que se sente junto ao desconhecido. Um choque entre o que a razão teórica pode conceber com aquilo que se pode sentir. A razão

\footnotetext{
${ }^{7}$ Apud PUC-Rio; certificação digital nº 0710668/CA
} 
difere da imaginação, oscilando entre a sensação e o conceito, cabendo a imaginação fazer a ponte. Esta dicotomia produz um choque, não permitindo ao sujeito formar um entendimento para essa inadequação.

O Sublime dinâmico por sua vez lida com forças e potencias da natureza que ultrapassam aos homens e os confronta com suas fraquezas, lembrando a alma de seu destino supra sensível. Desperta sentimentos religiosos, torna o homem consciente de sua impotência perante Deus; sente medo e reconhece seu próprio fracasso. Um prazer negativo em desacordo experimentado pelo contraste (Kontrast) entre as faculdades.

The inadequacy itself is the arousal in us of the feeling that we have within us a supersensible power; and what is absolutely large is not an object of sense, but is the use that judgment makes naturally of certain objects so as to [arouse] this (feeling), and in contrast with that use any other use is small. Hence what is to be called Sublime is not the object, but the attunement that the intellect [gets] through a certain presentation that occupies reflective judgment. ${ }^{8}$

O Belo e o Sublime agradam por si mesmos. O Belo é sempre da natureza e promove um sentimento de exaltação da vida, pois revela harmonia e prazer com a forma do objeto e seu limite. No Sublime, o prazer passa por um desprazer inicial, resultado de uma sobrecarga da imaginação cuja magnitude do que está sendo observado ultrapassa a intuição sensível. Ocorre de maneira indireta, promovendo sentimentos desproporcionados que geram dúvidas e medo. 0 Sublime não está na natureza, está no espírito sensível.

"O Sublime kantiano faz com que o homem realize, transcendentalmente, a experiência da infinidade; e isso no seu novo lar: a interioridade subjetiva. 0 Sublime não pertence aos objetos, nem às obras de arte, segundo Kant. Ele é um sentimento transcendental negativo que faz com que o homem sinta sua impotência ante o absoluto Inteligível”. ${ }^{9}$

\footnotetext{
${ }^{8}$ Kant, Critique of Judgment, apud Quigley, 2012.

${ }^{9}$ Brum, 1999: 62.
} 
Kant introduz um pensamento onde as esferas do conhecimento, da moral e da estética são separadas para ser possível criar pontes e novas relações entre si. É considerado como um marco na modernidade filosófica, pois torna possível o convívio simultâneo entre essas esferas.

A estética kantiana é a matriz da estética romântica.

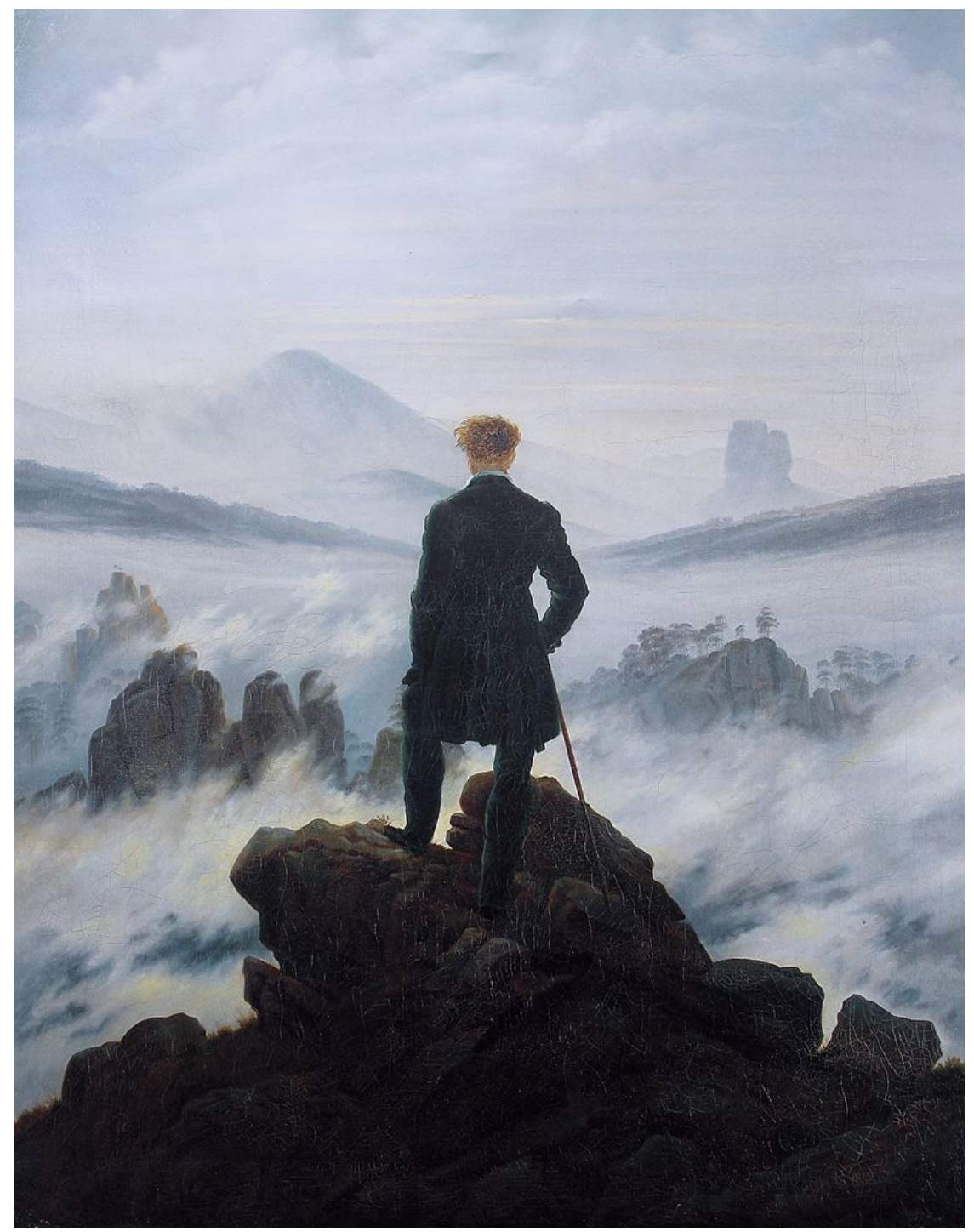

FIGURA 6_Caspar David Friedrich, Caminhante sobre o mar de névoa (c.1817)

A Natureza assumiu no período Romântico alemão um papel preponderante na sua representação. Para o pintor romântico alemão Caspar David Friedrich (1774-1840) esta representação de dava com uma complexa interação entre impressão visual e reflexão mental e 
emocional, retratando em sua obra uma "paisagem de sentimento", como dito por ele mesmo, uma imagem seelenvoll, "plena de alma". ${ }^{10}$ A representação simultânea de poder e de grandeza destacadas na obra, são para Burke e Kant a identificação de que algo muito maior está se dando neste momento. Não se trata de algo Belo, já que lembra ao homem suas fraquezas e seus limites frente ao imponderável. Revelam uma perplexidade frente a um passado nostálgico e perdido, retratado pelas ruínas enevoadas. Uma experiência sublime de impotência frente a cena que se descortina, repleta de devoção silenciosa, enlevada, como poderia sugerir o Sublime de Longino.

"Por trás da atração dos cenários naturais, da fruição voluptuosa da paisagem [...]; por trás do nomadismo espiritual desses aprendizes [...] por trás do nomadismo geográfico [...], a busca do sublime ou do exótico, dos recantos solitários que tranqüilizam, das paisagens remotas que acendem o desejo da terra paradisíaca, ou de lugares em ruínas, abandonadas pelo homem, que despertam para a nostalgia da terra perdida - por trás desses aspectos do culto da Natureza, enquadrados num confronto dramático com o mundo, está silhuetada a tácita insatisfação com o todo da cultura, misto de afastamento desencantado e de reprovação à sociedade, depois do assomo libertário do idealismo político de 1789". ${ }^{11}$

${ }^{10}$ Wolf, 2003: 9.

${ }^{11}$ Em Benedito Nunes, "A visão romântica" in Guinsburg, 1978: 68. 


\section{O Romantismo}

\subsection{0 contexto histórico}

Antecedido pelo século das luzes, o Romantismo surge na Europa, ao final do século XIX como um movimento artístico, político e filosófico e como uma escola historicamente definida, com respostas próprias às questões de seu tempo. Para o sociólogo Octávio Paz, o Romantismo, "se não foi uma religião, foi algo mais que uma estética e uma filosofia: um modo de pensar, sentir, enamorar-se, combater, viajar(...) Um modo de viver e um modo de morrer."1

É comum circunscrever o âmbito emergente do Romantismo aos ingleses e alemães. No século XVI, a Reforma Protestante havia exercido grande influencia ao admitir que a revelação pessoal religiosa se desse à nível pessoal permitindo uma liberdade espiritual, cujo sentido para o homem, aconteceria nele mesmo. Ao propor a superação do enfoque teológico judaico-cristão, cuja concepção teocêntrica concebia a história como um ciclo de revelação divina, o Romantismo revê também a concepção clássica da História que a valoriza como produto das "vidas ilustres", nelas compreendidas os

${ }^{1}$ Octavio Paz, "A outra voz" in Duarte, 2011: 11. 
sábios, filósofos, heróis, gênios, que iluminam e melhoram o homem e que a partir deles permitem o aperfeiçoamento e o progresso de suas instituições.

Os efeitos e a importância da Revolução Francesa, em 1789, produziram ecos próprios na Alemanha que, por não possuir os recursos econômicos e políticos como os franceses, estavam impossibilitados de concretizar uma revolução material. Fragmentados em uma população agrária, sem uma classe média que pudesse se opor ao governo, os alemães procuraram em sua literatura e na filosofia, o espírito do período nascente. Segundo o filósofo Pedro Duarte, "a França buscava realizar a liberdade, já a Alemanha ocupavase com a idéia de liberdade". 2

Assim, ao instalar a noção de progresso em substituição ao arbítrio divino, o Romantismo abandona o discurso histórico descritivo para se tornar interpretativo; “é a história que produz a civilização. Mas não a História, e sim as histórias". ${ }^{3}$ Desse modo busca uma aproximação do mundo às realidades, não somente dos ambientes físicos. Procura um tempo mais real, em sintonia com o mundo e seus acontecimentos, incorporando ao mesmo tempo, o estudo do desenvolvimento dos povos, de sua cultura erudita e seu saber popular, seu espírito coletivo, práticas e sua existência material e espiritual.

"A história romântica traça a trajetória de cada povo, pais ou nação como se ela fosse imbuída de um telos, de uma finalidade a presidir-lhe o sentido de sua existência (...)"4, afirma Hegel. Para ele, a idéia, ao procurar o caminho do espírito agrupa ambientes geo-culturais em grandes comunidades (o mundo oriental, o Greco-romano e o moderno) incorporando o seu passado e o seu futuro, o dentro e fora, jamais precisamente aqui ou agora, sempre em um devir constante, sem jamais ser definitivo. ${ }^{5}$

\footnotetext{
${ }^{2}$ Duarte, 2011: 13

${ }^{3}$ Guinsburg, 1978: 13.

${ }^{4}$ Idem: 18.

${ }^{5}$ A estética hegeliana, na sua forma particular, afirma que cada arte pode transbordar seu âmbito temporal e invadir dialeticamente o próximo período. Baseia-se na ideia de que tudo que é real pode vir a ser compreendido se não no momento, em um dia, quando se concretizar.
} 
Segundo o historiador Jacob Guinsburg (1921), “o romantismo é um fato histórico e, mais do que isso, é o fato histórico que assimila, na história da consciência humana, a relevância da consciência histórica", não se simplificando como uma configuração de estilo definidas como no Classicismo, no Barroco, no Maneirismo.

\subsection{O movimento Sturm und Drang}

A Reforma Protestante resultou na ruptura e afastamento por cerca de dois séculos da cultura latina, florescida com a Renascença Italiana. Para os italianos, a inspiração se dava na arte antiga e na natureza, ambas conduzindo à razão. Já o Romantismo alemão, através de Lutero caracterizou-se por uma reabilitação de valores religiosos e da fé, conduzindo ao sobrenatural, ao conhecimento em busca de uma educação que melhor atendesse aos atributos humanos, submetidos ao chamado divino de cada indivíduo. Segundo Gerd Bornheim, "se a vitória nos países latinos cabe ao racionalismo, na Alemanha é que o irracionalismo se introduz, constituindo-se em uma das presenças constantes ao longo de toda a cultura alemã."6

No século XXVIII, surge um primeiro movimento alemão de integração e assimilação da cultura européia (Aufklarung) como reação ainda ao isolamento promovido pela Reforma. É durante os anos 1770 a 1780, que nasce e se estabelece o movimento pré-romântico literário alemão Sturm und Drang (tempestade e ímpeto) como resposta ao racionalismo iluminista e ao classicismo francês que ainda exerciam na Alemanha uma grande influência estética e cultural. 0 movimento, que antecedeu a Revolução Francesa (17891799) adotou a revista "Athenaeum", fundada por Schlegel (1772-1829) como espaço para a colaboração dos textos de Goethe, Schiller e Herder. Os Stürmers eram contra a literatura vigente e incentivaram uma poesia mística com raízes locais, em fontes medievais e nórdicas, selvagem e espontânea, com destaque para o efeito da emoção, imediata e poderosa prevalecendo

\footnotetext{
${ }^{6}$ Gerd Bornheim: "A filosofia do Romantismo" in Guinsburg, 1978: 78.
} 
sobre a razão. Para os Stürmers é a irracionalidade que se torna tema, valorizando a figura do Gênio ao máximo, onde a ordem, a virtude e a moral são substituídas pela força e pelo caos criativos.

O pensamento do suiço Jean-Jacques Rousseau (1712-1778) contagiou profundamente as futuras gerações através de suas idéias democráticas, de moral rebelde com enorme repercussão nas esferas políticas e social, nas artes e nas letras. A natureza para Rousseau é baseada na interioridade do ser, oposta ao sentido cartesiano e enciclopedista de cunho objetivo, racional e matematizado que são característicos dos produtos da cultura e da ciência. Para Rousseau, cultura e natureza são mundos que se opõem, antiéticos e que se excluem:

"Entremos novamente em nós mesmo porque a partir dessa interioridade podemos compreender a natureza, e uma natureza isenta ainda da mácula de mãos humanas, estranha e anterior à cultura, de uma pureza divina e que nos pode revelar o Absoluto." 7

As idéias de Rousseau encontram muitos ecos no pré-Romantismo alemão. 0 espírito do "gênio" - figura que expressa ao máximo a natureza é absorvido pelo movimento Sturm und Drang. De características insubmissas a qualquer definição, o gênio apresenta-se como a própria força da natureza. Não é a razão que o define e sim os subterrâneos de suas idéias e de seus sentimentos ao que os românticos irão chamar de inconsciente, zona escura e original a ser explorada.

Com Rousseau, o pessimismo ganha espaço na sociedade, resultante de um entendimento sobre a natureza humana primitiva sendo corrompida pela cultura e pelas desigualdades promovidas pela propriedade. Em sociedade, o ser puro e inocente se perverte, surgindo a imagem do "bom selvagem", integro e primitivo. Estes seres, vislumbrados nos povos indígenas, de padrões não usuais aos padrões europeus; as crianças e jovens, saem da 
obscuridade e se tornam tema do Romantismo pois estariam mais perto da natureza virginal, livres para serem espontâneos e intuitivos. "Tudo que sai da mão do criador é bom e tudo se perde nas mãos do homem". ${ }^{8}$

Neste período inicial do Romantismo, o movimento Sturm und Drang busca também as origens dos povos e valoriza as civilizações, destacando suas características particulares e originais além de seus elementos físicos, vitais e espirituais para acentuar e definir o conceito de nação. Em sua síntese, vai propor definir a personalidade cultural e nacional de cada povo, surgindo um despertar para uma consciência nacional.

\subsection{A estética de Fichte, Schelling, Goethe e Schiller}

Baseado inicialmente nas teorias filosóficas do empirista escocês John Locke (1632-1704) para quem a experiência está na base do conhecimento humano e também no inglês Shaftesbury (1671-1713) que realça a "moral do sentimento", o Romantismo, concomitante ao ambiente do idealismo alemão de Kant foi também alimentado com o pensamento dos filósofos Friedrich Schlegel (1772-1829), Johann Gottlieb Fichte (1762-1814) e Friedrich Schelling (1775-1854).

Ao dualismo irredutível entre o mundo da natureza e o mundo da espiritualidade, na oposição entre mundo sensível, regulado pelo determinismo de causas e efeitos e o mundo espiritual de um homem dotado de desejos e instintos, Kant construiu uma realidade de liberdade dos valores morais, que permite ao homem uma autonomia de ações. A este princípio que não conhece condicionamento, Kant chama de "imperativo categórico" este princípio que não conhece condicionamento, desdobrando sua ética ao admitir que "devemos fazer o nosso dever pelo dever mesmo": uma moral do dever puro. ${ }^{9}$

\footnotetext{
${ }^{8}$ Em Anatol Rosenfeld e J. Guinsburg, "Romantismo e Classicismo" in Guinsburg, 1978: 262.

${ }^{9}$ Em Gerd Bornheim, "A filosofia do Romantismo” in Guinsburg, 1978: 85.
} 
Fichte, filósofo idealista, busca resolver a antinomia entre sensibilidade e entendimento, entre ciência e moral através do espírito que substitui a razão. Como "eu", entende uma autoconsciência pura, não particular de uma pessoa determinada mas como algo de divino e absoluto que o homem traz em si. Ao pensar um "eu" distinto do mundo, introduz a idéia do mundo independente deste "eu". Há eu e há o mundo. Considera o "ser" como uma contradição que não se resolve, já que o "eu" não é o todo portanto é limitado e sujeito à própria finitude.

Desse modo, Fichte aciona a idéia de intuição intelectual, negada por Kant e agora revalorizada na filosofia romântica para alcançar o 'eu" puro. " Amparado por esta contradição dialética, o Romantismo encontra seu âmago.

Já Schelling parte de Kant para sobrepor a razão (vermunt) o espírito (geist) e se utiliza da história para explicar a arte como sendo a manifestação temporal do absoluto. Schelling é uma vertente realista do eu. 0 geist não se confunde com o "eu", existe também na natureza sendo tão espiritual quanto o homem, subjetivo e interiorizado. Em seu entendimento é na arte que se dá o reconciliação entre o espírito e a natureza para assim se revelar o absoluto. Ainda para Schelling, um objeto de arte é ao mesmo tempo uma idéia e um objeto; a realização entre o homem e a natureza cuja intuição estética, baseada no impulso, no inconsciente se objetiva no objeto visando o real e o ideal. A arte se dá pelos opostos apresentando essa identidade original: claroescuro; luz e obscuridade; luz e trevas.

Para Schelling, essa identidade dos opostos não se dá a posteriori, não existe somente apos o aparecimento da obra, mas existe antes do mundo ser criado, retirada da obscuridade do cosmos e a história seria uma protohistória já que revela sua própria anterioridade.

Schelling afirmava ser na obra de arte que se realiza a unidade entre natureza e espírito, entre consciência e sentimento e que "a concepção que a filosofia se faz artificialmente da natureza, é para a arte a concepção natural e original"10. Para ele, a arte se apresenta como a revelação do encontro de uma memória escondida, no coração da natureza onde aparência e verdade 
se encontram. É na pintura que se encontra o apaziguamento entre essas duas potencias originais da natureza: luz e cor. Segundo Shelling, a arte encontra a força criadora que faz as coisas nascerem. 0 artista ultrapassa a natureza real e encontra a natureza naturanti, a beleza viva, animado por sua força interior oriunda do fundo vazio, do abismo.

A produção da obra de arte demonstrada por sua concretude e materialidade concilia esta necessidade e finalidade de união. É uma tentativa de síntese que se dá a partir do conflito entre a livre criação espiritual do artista e sua necessidade inconsciente. Desta forma, ao coincidir a intuição estética com a intuição intelectual, Schelling descreve uma apreensão do Absoluto cujo resultado se dá na obra de arte e que seria a concretização da intuição intelectual tornada objetiva.

“Toda realidade constitui uma unidade fundamental: a natureza é espírito visível e o espírito é natureza invisível, e isso nos é revelado abstratamente pela filosofia e concretamente pela arte."11

A complementaridade entre arte e natureza, foi reafirmada por Johann Wolfgang Von Goethe (1749-1832) na Máxima (Id.823) quando o belo é caracterizado como uma "[...] manifestação das leis secretas da natureza, as quais sem essa aparição teriam permanecido eternamente secretas" ${ }^{12}$. A arte realiza o que a natureza não consegue realizar, isto é dar uma forma visível e acabada desvendando os segredos que se escondem na natureza, não revelados no mundo natural. "Todo belo da arte", segundo Goethe "é, em pequena escala, uma copia do belo supremo, no todo da natureza" (Goethe,2008:62), que toda a natureza “[...] seria para nós o belo supremo",[...] se pudéssemos abrangê-la por um instante" (Ibd). ${ }^{13}$

Ao descrever sua experiência ao visitar a Catedral de Strasbourg, Goethe se deparou com o inexplicável. Amparado pelo conhecimento do bom-gosto que reagia negativamente ao estilo Gótico e seus ornamentos excessivos, deparou-se com a figura de um monstro disforme e crispado,

\footnotetext{
11 Ibid: 103

12 Guidotti, 2011: pp.118-131

${ }^{13}$ Idem
} 
aproximando-se do que Kant descreve como uma experiência sublime: uma imagem que apraz por si próprio e reivindica o sentimento de prazer, mas sem reivindicar o conhecimento do objeto. Essa experiência produz em Goethe uma visão grandiosa onde o "[...] espírito humano quando obra de seu irmão é tão sublime que ele deve apenas se ajoelhar e adorar." 14

Goethe se aproxima de Kant em sua visão do sublime ao admitir uma incapacidade de compreensão de um objeto quando a imaginação, atrelada ao mundo sensível, não consegue compreender o ilimitado, tornando-se inadequada às idéias da razão e gerando um sentimento de impotência, de prazer negativo, um abalo nas forças vitais. Tanto Goethe como Kant admitem que é este sentimento de impotência ante a grandeza que permitirá ao espectador elevar-se frente a tal grandeza. 0 sentimento obtido no sublime é o prazer no desprazer, pois "na verdade encontramos a nossa própria limitação na incomensurabilidade da natureza“. 0 sublime não está ligado à uma representação de qualquer objeto, à sua presença, mas a um sentimento." Por isso, diz Kant, de uma pessoa incapaz de contemplar o belo se diz que "não tem gosto" e, do sublime, "que não tem sentimento". 15

Friedrich Schiller (1759-1808) introduz a idéia de uma educação estética. Corresponde-se com Goethe. Acha, como Rousseau que os homens são sensíveis a um aprimoramento estético e que a arte pode servir à humanidade e transformar a sociedade. Acredita na educação pelo Belo. Afirma que nem Burke nem Kant estão corretos pois o entendimento somente se realizará através da pulsão (triebe) que ocorre entre a razão e a sensibilidade. Schiller contrapõe instinto - sensações estáticas e básicas que satisfazem as necessidades - com as pulsões, energias dinâmicas e instintos próprios da natureza humana. E diferentemente de Kant que busca a transcendência, Schiller busca eco na natureza humana para assim um sentido à arte.

A beleza agrada por criar harmonia entre a razão e a sensibilidade; uma conciliação entre instinto formal e instinto sensível. Esta energia dinâmica

14 Ibid: 127.

${ }^{15}$ Id. Ibid: 130. 
"triebe" - pulsão - pode ainda ser aperfeiçoada sob a influência da educação e almeja como ideal, uma vida em harmonia entre a natureza e a virtude. A idéia de que a arte pode transformar a sociedade surge com Schiller e sugere um Estado ideal onde o Belo educa moralmente através de uma democracia estética. Ao pretender unir a subjetividade e transcendência kantiana do sujeito com o forte sentido da natureza de Goethe, Schiller via a arte como o único caminho para conciliação e para a dignificação do homem. A arte não é inútil e pode servir à humanidade.

\subsection{O sujeito romântico}

O Ocidente, na passagem do século XVII para o século XVII, através de Spinoza, Voltaire e Diderot, elabora uma visão da razão que se sobrepõe à história sagrada, questionando e subvertendo os fundamentos das instituições religiosas. Esse processo culmina com Rousseau, para ser entendido como um produto das condições da vida em sociedade e das formas de contato social.

Nesse contexto, o personagem romântico encarna uma vontade social que, apesar de subjetiva, é dotada de um espírito central, nevrálgico, alimentado por uma existência conjunta. Surge uma nova mito-poética histórica enriquecida pela variedade das epopéias coletivas e heróis nacionais. 0 Romantismo une as sociedades em mundos, nações, em raças possuidoras de culturas ao invés de civilizações, gerando identidades variadas e grupos diferenciados.

Para o historiador Benedito Nunes, "a essa concepção do mundo romântico preponderantemente idealista e metafísica, percorrida por um afã de totalidade e unidade, próprio da sensibilidade conflitiva que a impulsionou e polarizada por sentimentos extremos e atitudes antagônicas, comportando uma vivência da Natureza física, um poder mitogênico: a essa concepção do mundo, que separou do universo cultural a literatura e a arte, transformando-as na instância privilegiada de uma só atividade poética, supra-ordenadora das correlações significativas da cultura, concomitantemente ligada à 
afirmação do indivíduo e ao conhecimento da Natureza: a essa concepção do mundo corresponde o Romantismo estritamente considerado, que conjuga e solidariza as duas categorias, a psicológica e a histórica, antes referidas, do conceito respectivo. Mas assim delimitada, a visão romântica, que se interrompe com o advento da modernidade, não esgota o alcance do Romantismo."16

A subjetividade, a vida interior deu ao sujeito romântico o espaço para manifestações de espiritualidade, elevação, profundeza, apresentando sua singularidade e expressão no plano da expressão artística. Segundo Nunes, o conceito de "expressão" passa a significar uma "tradução" da personalidade. Este eu transcende a Natureza física, cujas formas naturais compreendem também as formas expressivas e portanto simbólicas.

A arte na era romântica se estrutura em um tecido múltiplo constituído por componentes culturais complexos e por diversificadas conjunturas formais para atender a seus ideais. Os artistas primam pela espontaneidade e pela valorização dos sentimentos e da intuição e pelos valores passionais em busca de representar certa densidade da vida. São artistas integrados ao seu tempo e invocam simultaneamente o passado e o futuro, ancorados na imaginação e nas situações de cunho subjetivo.

O Romantismo promove uma grande revolução no sentimento da vida e em sua cosmo-visão. No campo da crença histórica, o Romantismo atenta para o particular, para o singular e trata a história como uma sucessão fenomenal individualizada, diferindo do iluminismo que se baseia na faculdade racional comum a todos indivíduos. 0 indivíduo do Romantismo é zado naquilo que o distingue do outro.

Os artistas românticos experimentam a contradição de aspirar ao absoluto e saber que não o alcançarão. Admitem que os gregos foram os que mais chegaram mais perto deste modelo, pois consideram a Grécia a origem metafísica do Ocidente. Com a consciência das ruínas gregas, vem também o sonho nostálgico daquela sociedade, de sua beleza inacessível e atemporal.

\footnotetext{
${ }^{16}$ Em Benedito Nunes, a in A visão romântica" in Guinsburg 1978: 53.
} 
Neste contexto surge um revivalismo do estilo Gótico, retomado e reincorporado, valorizado por artistas ao fazerem equivaler, em suas obras os elementos gregos e os góticos.

Schelling, ao manifestar a importância do claro-escuro na pintura, da luz e do obscuro, do jogo entre luz e trevas busca com a identidade dos opostos a identidade original e harmonia que são encontradas na arte que não se manifesta na síntese construída a posteriori. A identidade dos opostos existe, preservada e oculta na "imanência abissal da natureza" 17 da natureza, opostos unidos, escondidos. É na obra de arte que é manifesto o encontro, a unidade.

\subsection{O panorama artístico: Neoclassicismo x Romantismo}

Segundo Hegel, o espírito romântico pode ser localizado em momentos diferentes da história. A melancolia, a dramaticidade de temperamentos e o culto à natureza encontrados em Tintoretto, Rubens e Rembrandt e também na literatura com Shakespeare e Dante demonstram que a exposição de sentimentos em suas obras são valores sensíveis que exercem um poderoso domínio sobre a mente e sobre o mundo físico natural.

O Romantismo recusa a visão racionalista e estética e os valores sustentados pelo Neoclassicismo e pelo Academicismo. Confronta-se com a convivência da arte grega rememorada e ainda paradigma da beleza ideal e atemporal, civilização revivida e redescoberta então recentemente pelas escavações arqueológicas. Esta Grécia romântica não é a antiga, tampouco são as escavações de Winckelman (1717-1768) e suas ruínas. Para Hegel já se configura como uma Grécia histórica, que põe em cheque a idéia de beleza eterna. Apesar de insistir com a idéia de origem que intensifica um sentimento de continuidade histórica, torna também possível a contemplação da arte de um ponto de vista evolutivo. Este modelo grego agora revisitado, permite pensar um novo tipo de organização cultural e histórica, onde a idéia

\footnotetext{
${ }^{17}$ Citado por José Thomaz Brum em aula proferida em 15/03/2015, PUC-Rio.
} 
de arte é efêmera e que a beleza não é eterna. As ruínas gregas são testemunho de seu fim.

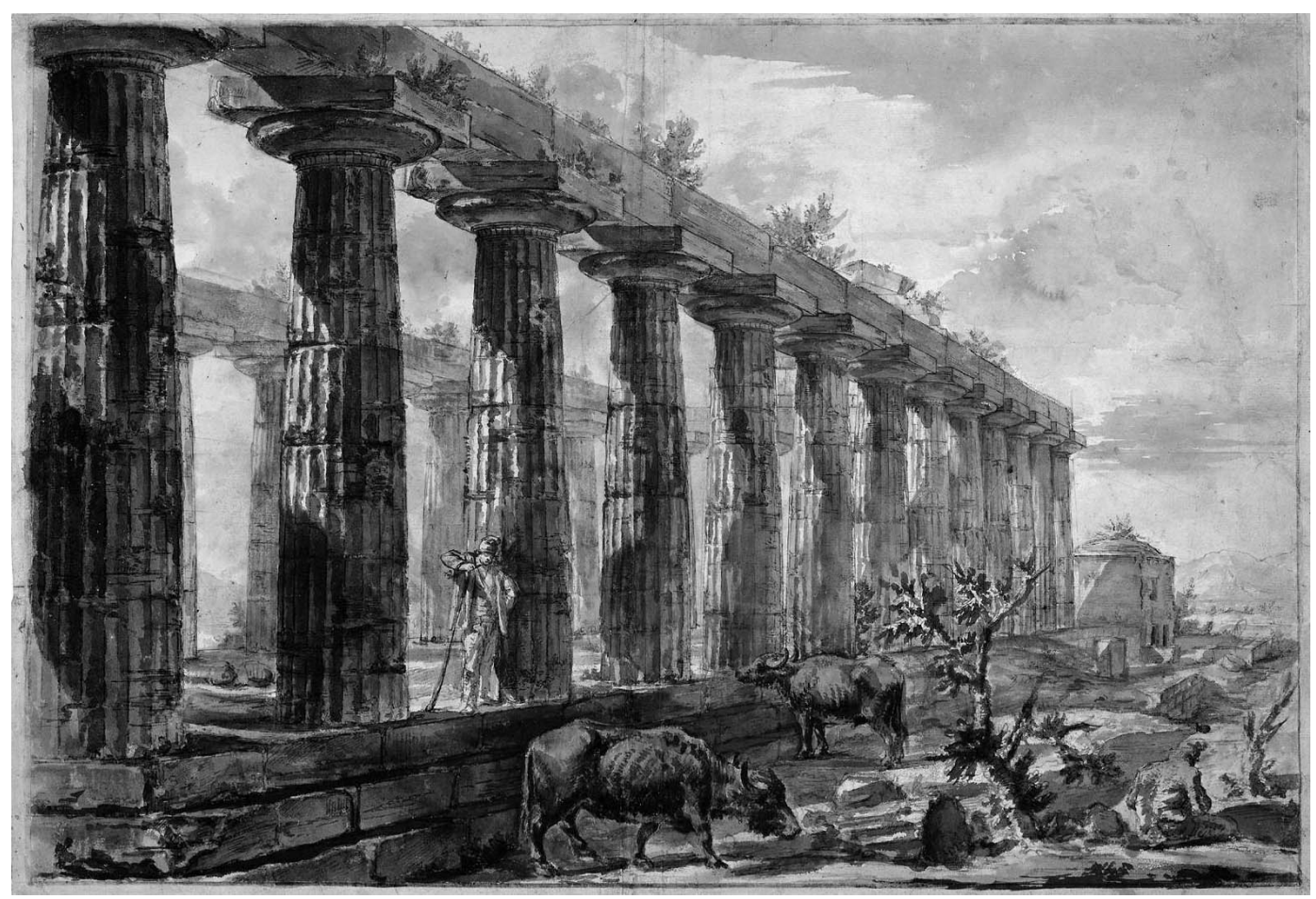

FIGURA 7_Giovanni Battista Piranesi (1720-1778). The temple of Athena, 1777.

Segundo Croce, em sua "Iniciação à estética", "o classicismo se destaca por seus elementos conjugados sob a ordem a harmonia, a objetividade, a ponderação, a proporção, a serenidade, a disciplina, o caráter apolíneo, secular, lúcido e luminoso. É o domínio do diurno. Avesso ao elemento noturno, o classicismo quer ser transparente e claro, racional“18. É através da obra de arte que imitando a natureza obtém sua harmonia alcançando as leis do universo.

A arte clássica é arquitetônica por natureza e centra seu pensamento, propõe e executa suas partes, em função de seu próprio equilíbrio. Está inserida, segundo Rosenfeld e Guinsburg em um "contexto estético onde a obra se coloca como um mundo autônomo, encerrado em si, válido em si."

${ }^{18}$ Em Anatol Rosenfeld e J. Guinsburg, "Romantismo e Classicismo” in Guinsburg, 1978: 262. 
"É um quadro contido dentro da moldura [...] sem visar nada que esteja fora." 19

As formas abertas do Romantismo investigam para além do enquadramento central. Os artistas românticos tem como proposta abrir o produto artístico, extrapolando sua estrutura e formas representativas. Gêneros até então considerados menores como o desenho, vão ganhar importância para trazer à tona o psicológico, o subjetivo, oferecendo ao expectador novas formas de apreensão da obra.

No contexto clássico, ocorre a invisibilidade da figura do autor, já que seus impulsos subjetivos são disciplinados para não permitir uma expressividade particular. A obra é objetiva e deve valer por si e não dizer algo sobre seu criador. Como não pretende ser diferenciada e individualizada, a arte clássica quer alcançar o geral e fixar-se no universalmente humano. É igualmente rígida em relação à separação das artes entre belas artes e aplicadas, não aceitando a interação entre suas formas tampouco permitindo uma invasão em seus estilos. A cada gênero correspondem preceitos e regras próprias para sua composição, sem permitir articulações entre si. No Classicismo o valor estético reside na obra produzida por um artista artesão que segue as regras estabelecidas e a elas se submete. 0 efeito da obra deve comunicar-se com seu público traduzindo, através de sua beleza, os valores morais e os ensinamentos nela contida. Através da boa forma a obra será capaz de falar à razão.

Por sua vez, em sua via artística, o Romantismo privilegia tendências e buscas que estejam no interior do artista, em seu mundo psíquico. A escola romântica desloca o misticismo de dentro para fora à espera de uma iluminação em particular. Com isso transforma em experiência psicológica o que seria uma prática religiosa, sujeita agora a uma experiência fervorosa, processada na intimidade do indivíduo. A beleza autêntica se encontra também no passado, na alma do povo onde se depositam suas lendas e imaginário.

19 Idem. 
O Romantismo também traz em si o culto ao gênio original, que possui uma força cósmica, inata e independente da cultura que interpreta e recria de maneira intuitiva e direta sob o impacto de uma inspiração espontânea e pessoal. Sua arte se opõe à arte clássica ao se recusar ser acabada e torneada segundo os padrões da perfeição e ao permitir seu surgimento de maneira sincera e autêntica. Nasce assim uma novo padrão estético de criação e também de avaliação e fruição da obra, cujo valor não está mais contido nela própria, já que incorpora subjetivamente o autor com toda a sua emoção e a exaltação de como foi criada. A obra tende assim a ser confundida com o autor, movimento inverso ao do Classicismo que oculta o autor atrás da obra. "Parafraseando Kant", diz Duarte, "podemos dizer por fim que, para os primeiros românticos, o Gênio sem gosto é cego e o gosto sem Gênio é vazio. Só quando ambos trabalham juntos, surge a obra de arte". ${ }^{20}$

Aspectos psicológicos se tornam evidentes, expondo os elementos particulares e característicos do indivíduo; aquilo que o distingue dentro do quadro social, da nação e da classe em que se encontra. Para Schlegel, em seu tratado "Sobre a Preguiça", um aspecto típico do Romantismo e de seu requinte reside na fadiga, de uma gente que já nasceu cansada."21

A efusão violenta de efeitos e paixões, as dissonâncias, a desarmonia são, segundo Croce, componentes da criação romântica: subjetivismo radical, exaltação dionisíaca em oposição à contenção apolínea do classicismo, preponderando o elemento noturno,uma inclinação ao mórbido. 0 característico, o caricato e o grotesco são formas de contraposição do Clássico, buscando captar sua verdade, sua "inteireza, sua Gestalt, sua configuração" 22 em busca de sua singularidade.

\footnotetext{
${ }^{20}$ Duarte, 2011: 81.

${ }^{21}$ Em Anatol Rosenfeld e J. Guinsburg, “Um encerramento" in Guinsburg, 1978: 283.

22 Em Anatol Rosenfeld e J. Guinsburg, "Romantismo e Classicismo" in Guinsburg, 1978: 269.
} 


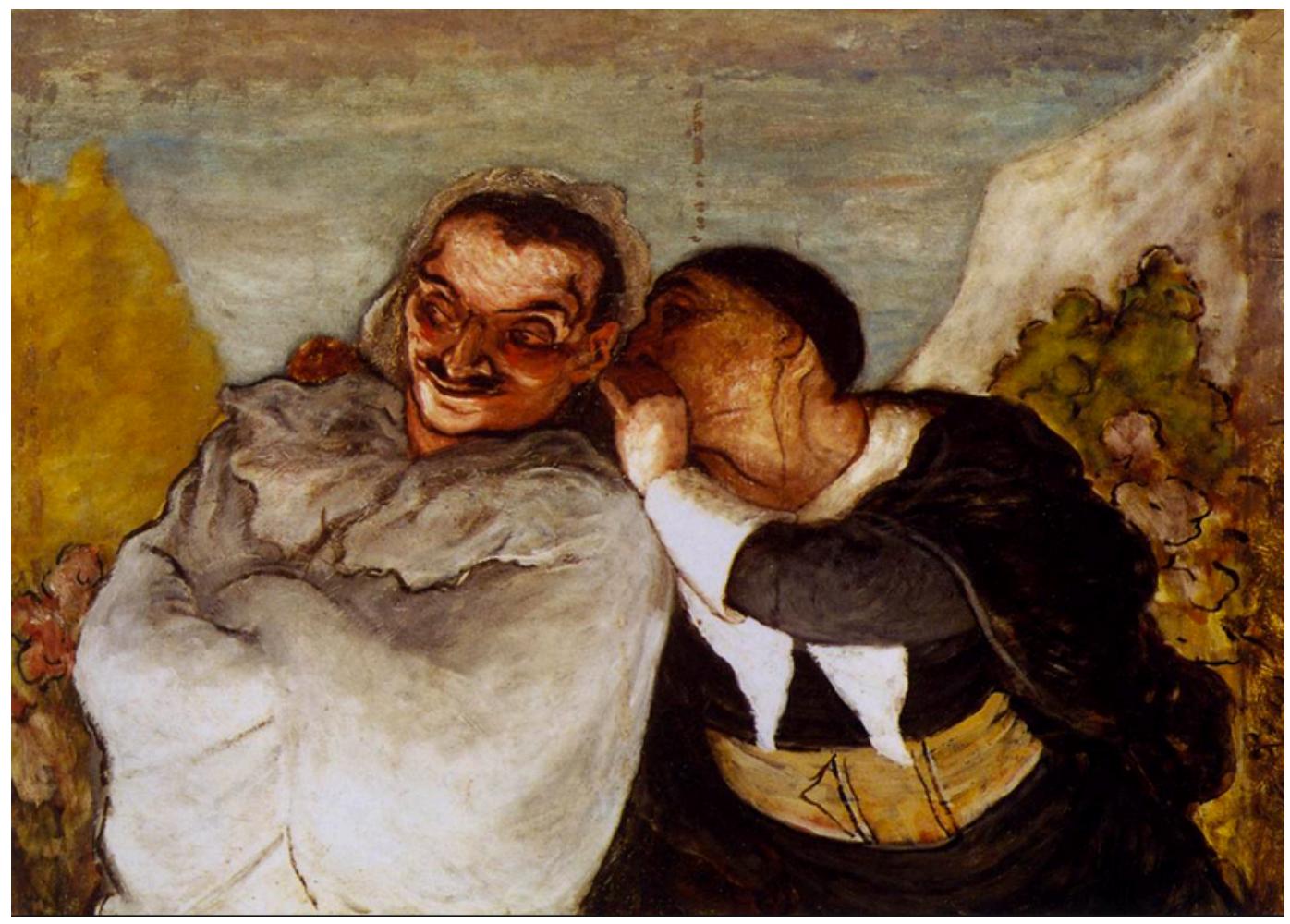

FIGURA 8_Honoré Daumier (1808-1879), Crispin and Scapin. 1858-60

Em confronto com o Clássico que retira o elemento do contexto para destacá-lo, o Romantismo o destaca dentro de seu ambiente, acentuando uma necessidade de, ao inscrevê-lo, acentuar sua adequação aos tempos e aos povos naquele momento. Fogem assim de uma arte segundo os cânones estabelecidos na Grécia antiga - que serviram ao seu povo naquele determinado tempo - para atender agora às necessidades de uma nova modalidade histórica.

Os Românticos vêem o homem como um ser fragmentado e como conseqüência são seres infelizes e desajustados gerando, na afirmativa de Rosenfeld e Guinsburg: "daí o sentimento de inadequação social; daí a aflição e a dor que recebem o nome geral de "mal du siècle", uma busca de evasão da realidade e um anseio atroz de unidade e síntese, que tanto marcam a "alma romântica".

$\mathrm{Na}$ síntese entre uma busca nas origens e em um passado remoto simultâneo a uma aspiração de comunhão cósmica em busca de uma união e fusão com o universo e sua infinitude, é onde o Romantismo encontra ou melhor, busca encontrar sua essência: prevalecer um sentimento, uma 
consciência do paraíso perdido de forma irremediável, dando ao infinito uma presença que assombra e angustia ao se abrir para o nada. Surge assim a obra romântica que valoriza o fragmento, o aforismo como tradução estilística de uma captação fugaz, de algo impossível de apreender em sua totalidade e que escapa a qualquer representação fixadora, utilizando-se dos efeitos obtidos por contornos evanescentes, esfumaçados, efeitos atmosféricos que promovem uma estética sensorial.

A representação através das formas rigorosamente estruturadas de Jacques-Louis David (1749-1825) e Ingres (1780-1867) dão lugar à representações de contornos evanescentes e efeitos atmosféricos já aparentes em John Constable (1776-1837); nas cenas e paisagens quase abstratas de Joseph Mallord William Turner (1775-1851) e também em Ferdinand Victor Eugène Delacroix (1798-1863) que afirmava "...nem sempre a pintura precisa de um tema" 23 .

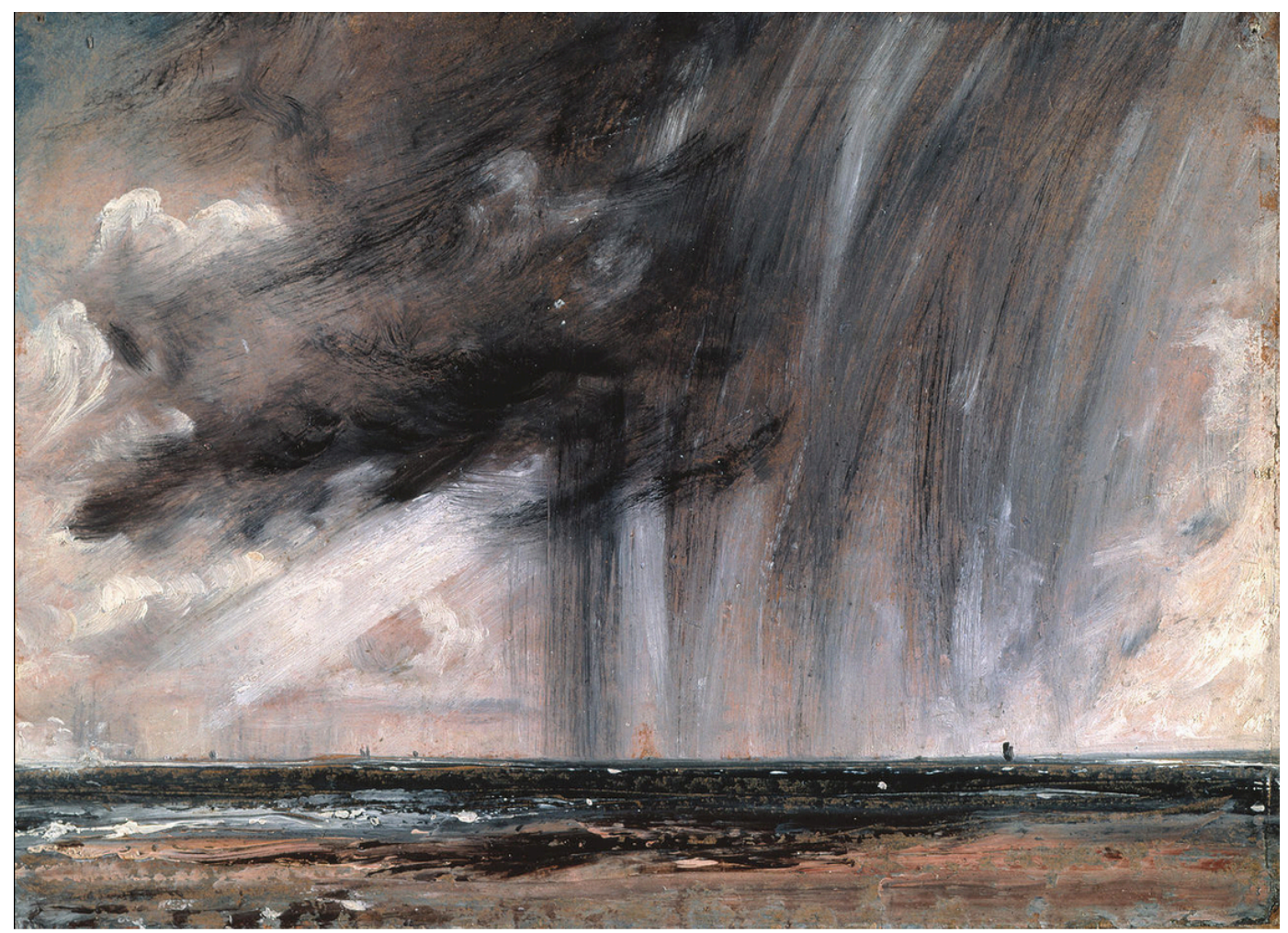

FIGURA 9_John Constable (1776-1837), Seascape Study with Rain c.1824

${ }^{23}$ https://pt.wikipedia.org/wiki/Eugene_Delacroix. Acesso em janeiro, 2016. 
Embora busquem a unidade e síntese, os românticos empenham-se em obter esta realização sintética não pela harmonização clássica, mas através da violência dos movimentos, pelo choque de contrastes e ênfase nas contradições e antagonismos, dando vazão às oscilações de temperamento. Essas expressões de dissociação que caracterizam o ser humano demonstram o caráter contraditório e cindido do espírito artístico que busca um resgate de sua inocência, não somente como retorno, mas acrescentado de sua cultura e conhecimento.

O Neoclassicismo do século XVIII cultiva a antiguidade greco-romana que vai se opor às extravagâncias e luxo do estilo rococó, representativo da arte cortesã. Assim, a tradição gótica, com seu estilo medieval e jardins de traçado informal, ganha espaço destacado como uma das expressões mais sintomáticas do gosto romântico.

Os salões de arte proliferam e crescem as exposições individuais; a circulação pública e a imprensa promovem novas perspectivas de apreciação; intensifica-se o colecionismo, demonstrando uma nova autonomia de aquisição, agora independente do Estado, da Igreja e dos Salões de Arte oficiais. É um período de alargamento do campo de ação e expressão artísticos, um período que vivencia uma transdiciplinaridade, exercitando novas linguagens e experimentando novas técnicas. 


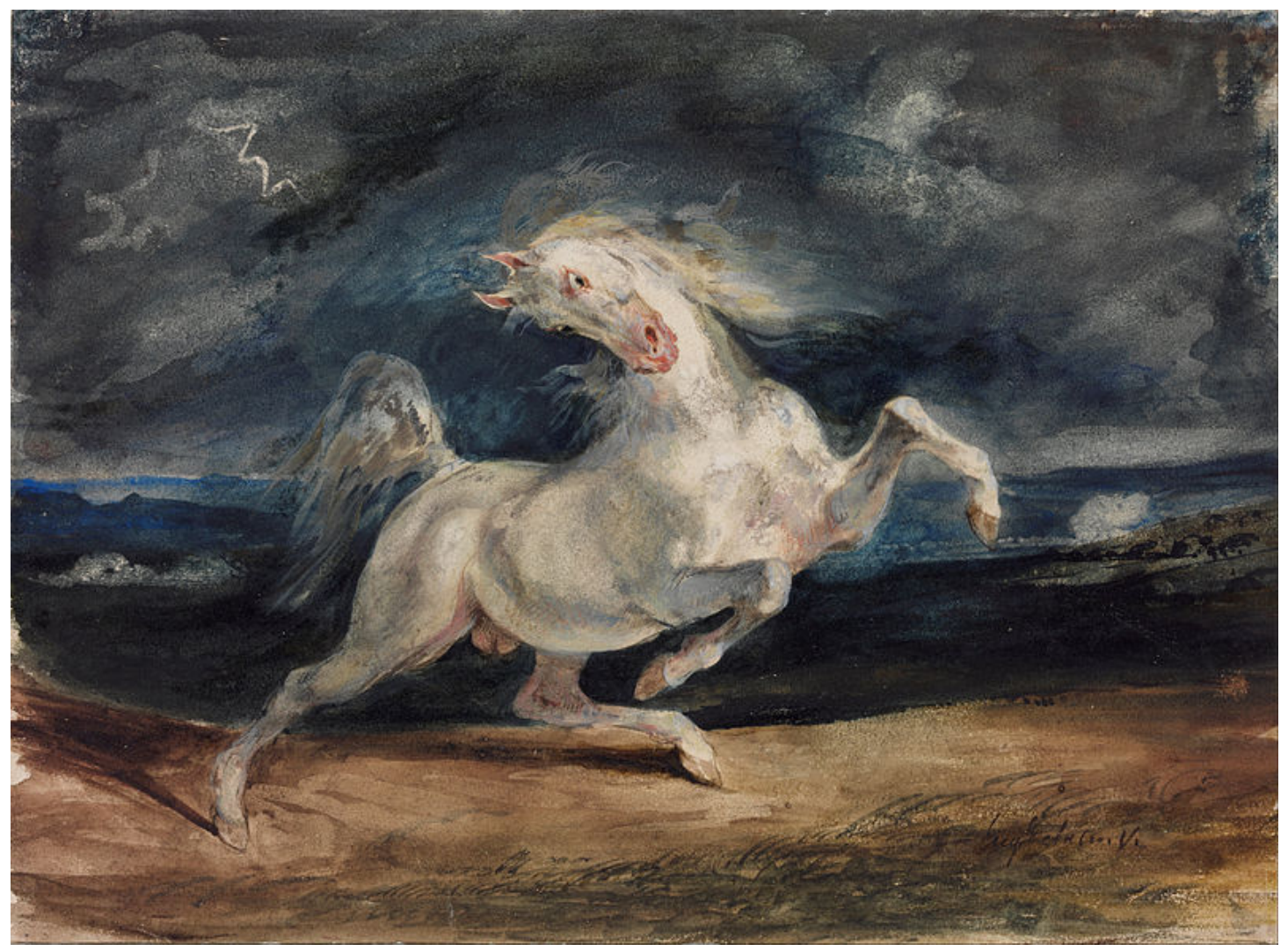

FIGURA 10_Eugène Delacroix (1798-1863), Horse Frightened by a Storm, 1842

Delacroix trouxe para suas telas um entusiasmo pela instabilidade, pela tensão obtida com o movimento da composição e pelo tratamento pictórico onde formas se esfumaçam, se diluem permitindo que a cor se liberte em busca de novos canais de expressão subjetiva. Na figura do animal, o movimento difuso da crina traduzindo o ímpeto do animal acentua o arrebatamento emocional, oposto a um tratamento clássico de obra, cujo domínio estrutural se daria pelo controle de sua composição. 


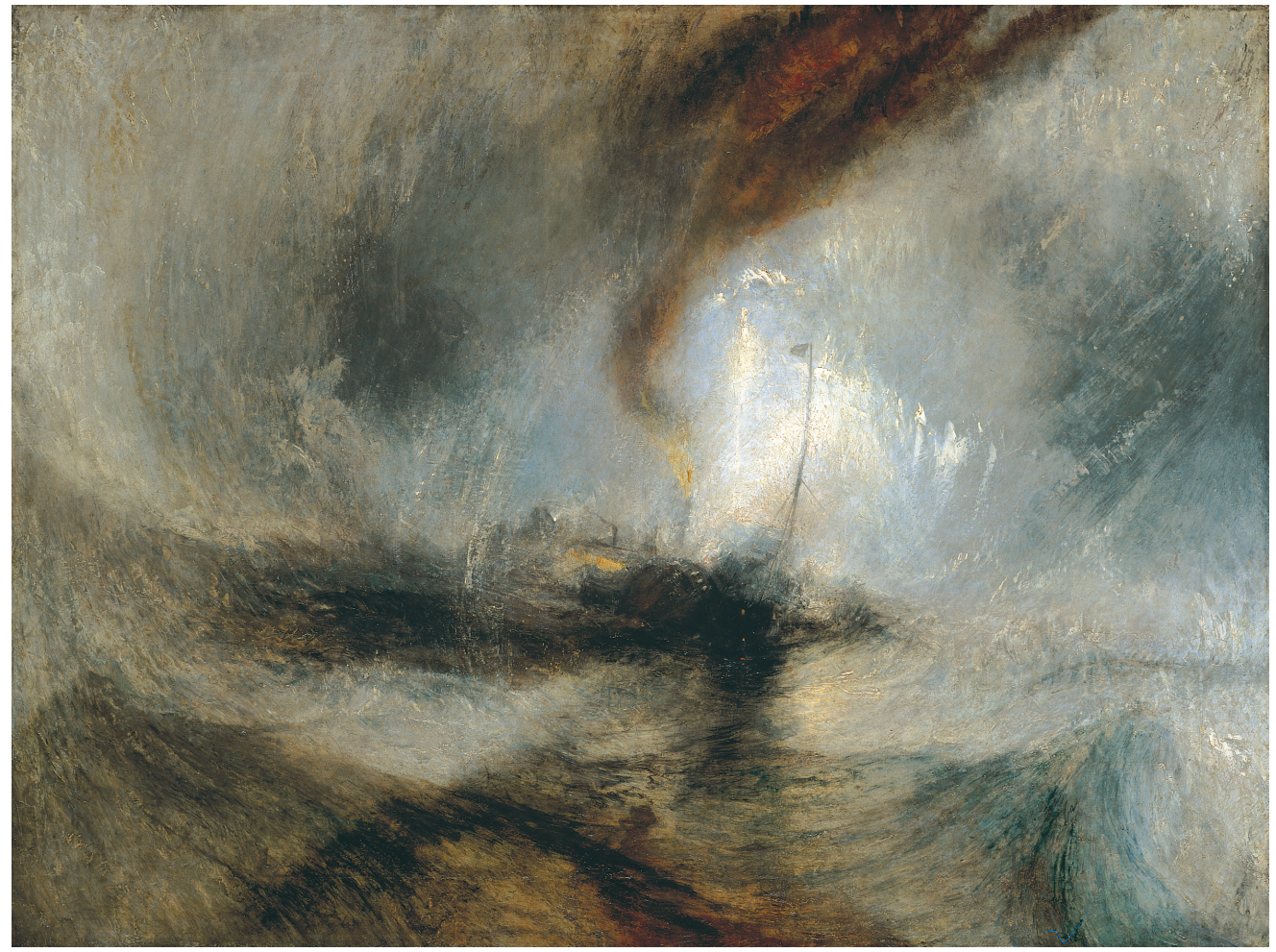

FIGURA 11_William Turner (1775-1851). Snow Storm, Steam-Boat off a Harbour's Mouth. $18 \overline{4} 2$

Para o pintor romântico Turner, a luz é a emanação do espírito divino. Situações voláteis, contornos evanescentes e difusos caracterizam uma estética de fruição sensorial que necessita de uma disposição de ânimo e intenção do espectador em face a ele. Uma cena narrada sob o artifício da pintura e que coloca em evidência a insignificância do espectador, ao instalá-lo no centro de um vórtice e um movimento espiral que aspira o olhar para uma situação de extrema tensão. Luz, cor e movimento, pinceladas vigorosas mas pouco definidas afastam-se da mimeses, abandona a cena-objeto estática para introduzir valores de caráter psicológicos e que segundo Kant, nos leva a um sublime de força, dinamismo cósmico onde se dá o poder avassalador da natureza. Essa experiência de poder, de magnificência são, sob a ótica de Burke componentes de uma experiência que por ser apenas a representação de uma cena, pode proporcionar um deligth. Alivio e dor. É para Argan uma vista emocionante, diferente do que chama de vista emocionada 24 ao se referir as obras de John Constable.

${ }^{24}$ Argan, 1998: 40 . 


\section{6}

\section{Considerações Finais}

Ao longo deste trabalho foi possível verificar como vários pensadores refletiram sobre o Belo e o Sublime, no âmbito do Romantismo. No rompimento com o Clássico, os românticos abriram caminho para a exposição de valores subjetivos até então submersos aos cânones estabelecidos, compreendendo desde a liberação da composição artística às novas técnicas de fatura da obra, incorporando simultaneamente novos significados simbólicos em novas temáticas artísticas.

Tendo expandido suas fronteiras tanto nas linguagens artísticas como nos meio de produção das obras, essas diversas possibilidades de expressão estéticas contribuíram para um pensamento caracterizado como de ruptura e de vanguarda, obtidos fundamentalmente pela conquistada auto-expressão do artista.

A filosofia de Kant contribuiu enormemente para a modernidade ao admitir que o sujeito se apresentasse com sua própria identidade. 0 artista romântico se libera de regras pré-estabelecidas e pode representar seus próprios sentimentos, transcendendo inclusive a perfeição desta representação.

Na obra dos artistas românticos o valor se desloca do produto para o próprio artista, para sua própria auto-expressão. A obra é a via de comu- 
nicação entre o interior e o exterior do criador, não necessitando de ser uma representação fiel nem bem acabada ou agradável. 0 que está em jogo é a subjetividade do autor. Nada mais contrastante do que opor-se aos valores das obras clássicas então vigentes, que promoviam através do artista artesão a serviço do estabelecido - a busca de agradar e ser útil a seu público, estando subordinado a um juízo de gosto e a consensos e incentivando um ajuste social precário.

Com o Romantismo, o modo de se ver as coisas permite o destempero, o irracional e uma certa falta de disciplina. Seus artistas se posicionam contra os padrões absolutistas anteriores e manifestam uma explosão libertadora em todos os segmentos da sociedade. 0 desajuste portanto, passa a ser um valor verdadeiro. Esse estranhamento, esse desconforto, essa angústia e desterro do homem romântico transforma sua vida em uma permanente cisão, procurando em sua forma aberta, sem fronteiras, uma fragmentação cultural deliberada. As indecisões, a perplexidade, a contemplação são motivos para a criação entre os românticos. A busca das diferenças; do Ocidente e do Oriente; da cultura e do mundo primitivo; a revalorização do mito; o colorido exótico, todas são manifestações que contribuem também para a construção da alma romântica.

A principal diferença entre o Belo e o Sublime encontradas no Romantismo é sua finalidade. 0 objeto do Belo se encontra no prazer da forma, agindo como símbolo da harmonia já que convém às nossas faculdades e agrada por si. O Belo de Kant promove serenidade, encanta por suas formas, limites e admitindo a ornamentação. O Sublime emociona, assombra. É amplitude, difusão e escapa a uma compreensão global.

Enquanto o Belo pacifica, o Sublime deve ser vivenciado como algo esmagador, perturbador e isso é o que constitui sua finalidade estética, oferecendo ao ser humano o usufruto deste sentimento. 0 desacordo entre a imaginação e a ideia promove uma experiência estética de "fracasso" já que o sensível não consegue dar forma aos conceitos, não os consegue representar. A razão exige mais do que a imaginação pode representar e o "fracasso" nessa tentativa possibilita a experiência do Sublime. Esta vivência não se dá 
através da característica do objeto mas através do sentimento humano que reflete sobre si próprio. Enquanto o Belo está na natureza, o Sublime se dá no espírito.

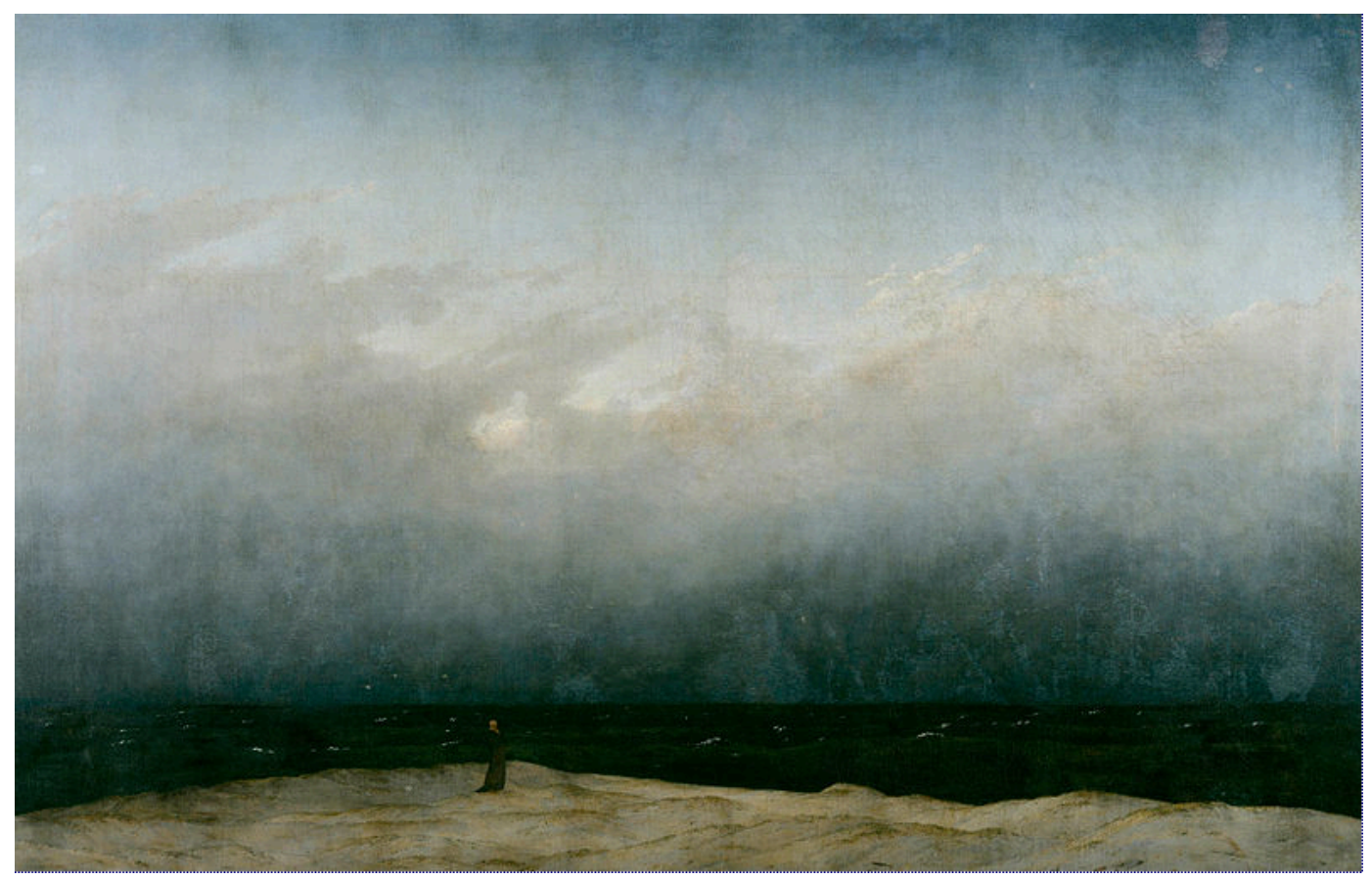

FIGURA 12_Caspar David Friedrich (1774-1840), Der Mönch am Meer, 1808-1810

A estética do Sublime influenciou enormemente as tendências artísticas que se seguiram ao Romantismo. Em sua forma libertada do Belo; na incorporação do real e do imaginário; no rompimento dos cânones expressivos, o Sublime permitiu às vanguardas que surgiam ampliar suas experiências representativas, surpreendendo o espectador com novas maneiras de afetálo com suas obras, assim como proporcionando novas possibilidades delas próprias serem julgadas. Ir além da apreensão da realidade, ultrapassar seu "justo meio" 1 . Obter no Sublime, no heróico, no incontido aspectos e abordagens poéticas e reflexivas, incorporando também o dionisíaco que reina nos subterrâneos dos sentimentos.

O Sublime do Romantismo configurou-se como um produto típico da vida e cultura urbana européia, onde o niilismo, a ironia, o cansaço e tédio se tornam motivos de representação. Considerando este panorama, o filósofo

\footnotetext{
${ }^{1}$ Em Anatol Rosenfeld e J. Guinsburg, “Um encerramento" in Guinsburg, 1978: 292.
} 
Paul Crowther (1953), estudioso do Sublime afirma que "no capitalismo moderno há um deslocamento do Sublime da natureza para a 'experiência' urbana" [...], "as vastas paisagens urbanas, a cidade do século XX como vasto domínio anônimo, são exemplos modernos do 'imenso', do 'incomensurável', do que 'transcende' o homem."2

Por sua vez, o pensador francês Jean François Lyotard (1924-1998), desloca o tema do Sublime para o final do século XX e partindo de Kant e sua experiência negativa do Sublime examina as vanguardas modernas, distanciando-se do Romantismo, caracterizado por seu absoluto inatingível e do Expressionismo, com sua interioridade inebriante. Lyotard aponta ser o Sublime um novo modo de sensibilidade da modernidade, onde a obra de arte moderna fala do "impessoal acontecimento" 3 do vazio e desamparo metafísicos da contemporaneidade.

Desajuste, desamparo, impossibilidade, vazio, nostalgia, foram experimentados pelo sujeito em sua subjetividade e auto-expressão e deram o tom ao Sublime no Romantismo. Se para Longino o Sublime foi o silêncio reverente, para Kant, foi a manifestação estética da experiência do fracasso. E em Hegel, o Sublime se dá na inadequação entre idéia e forma, entre o conceito e o conteúdo.

A investigação ocorrida nesta pesquisa, Reflexões sobre o Belo e o Sublime, possibilitou uma abordagem inicial que introduzisse os conceitos fundamentais destas duas categorias estéticas ocorridas no Romantismo. A cada tópico abordado, muitas portas novas se abriram, oferecendo outros tantos caminhos para pesquisa e leituras. Portanto, sem considerar este assunto sequer perto de estar concluído, caberia em uma nova pesquisa abordar de que maneira o Belo e o Sublime se manifestaram e se manifestam nos períodos que se seguem ao Romantismo: a Modernidade e a Pós-modernidade. Refletir sobre as obras de artistas como Barnett Newman (19051970), Mark Rothko (1903-1970), Walter de Maria (1935-2013), Robert

\footnotetext{
${ }^{2}$ Paul Crowther, apud Brum, 1999: 62.

${ }^{3}$ Brum, 1999: 65.
} 
Smithson (1938-1773), Anish Kapoor (1954), Anselm Kiefer (1945), para apenas citar alguns que trabalharam e ainda trabalham - de maneira muito próprias - com o Sublime.

Por fim, se no Classicismo a obra continha-se nela mesma, com a moldura configurando um limite físico entre obra e vida, o Romantismo expandiu fronteiras, invadindo a vida com suas obras, trazendo o íntimo do artista para a vida do espectador. No contemporâneo, arte e vida se misturam de tal maneira, tornando muitas vezes impossível discernir o dentro do fora, a vida da obra. 


\section{Referências Bibliográficas}

ARGAN, Giulio Carlo (1998). Arte Moderna. São Paulo: Cia. das Letras.

BARBOSA, Jair; "Sublime dinâmico e pintura: Turner e Pollock". Universidade Federal de Santa Catarina - UFSC (Florianópolis). Pesquisa pós-doutoral desenvolvida nas Universidades alemãs Hamburg e Frankfurt / Humboldt-Stifung (Alemanha/2008) e PUCPR (Curitiba 2008).

BRUM, José Thomaz. "Visões do Sublime: de Kant a Lyotard" in lleana Pradilla Cerón e Paulo Reis / orgs (1999). Kant, critica e Estética na Modernidade. São Paulo: Editora SENAC.

BURKE, Edmund (1993). Uma investigação filosófica sobre a origem de nossas idéias do Sublime e do Belo. Tradução e notas de Enid Abreu Dobránszky. Campinas, São Paulo: Editora Unicamp / Papirus.

CRANSTON, Maurice. The romantic movement. Cornwall: T.J.Press. 1994.

DUARTE, Pedro (2011). Estio do Tempo: Romantismo e estética moderna. Rio de Janeiro: Jorge Zahar Editor.

DUARTE, Rodrigo / org. (2012). O Belo Autônomo: textos clássicos de estética. 3.ed. Belo Horizonte: Autentica / Crisálida.

GUIDOTTI, Mirella (2011). "Imbricações entre Goethe e Kant: Arte, Natureza e Sublime" in Pandaemonium Germanicum, n¹7, Julho. São Paulo: Usp.

GUINSBURG, J /org (1978). O Romantismo. São Paulo: Perspectiva.

KANT, Immanuel (2012). "Critica da faculdade do juízo" in Duarte, Rodrigo (org). O Belo Autônomo, Textos clássicos de estética. Belo Horizonte: Autêntica Editorial.

- (1974). Crítica da Razão Pura. Trad. Valério Rohden. São Paulo, SP:

Abril Cultural.

MELVILLE, Herman (2008). Moby Dick. Tradução Irene Hirsh e Alexandre Barbosa de Souza. São Paulo: Cosac Naify, p.36.

PLATÃO (1980). Hipias Maior. Tradução de Carlos Alberto Nunes. Pará: Editora da UFPa.

QUIGLEY, Timothy (2012). "Kant: Notes, Critique of Judgment - The Sublime".

http://timothyquigley.net/vcs/kant-aesth_sum3.pdf, acesso em dezembro, 2015.

ROSSETTI, Micaela Lüdke (2014). "Burke, Kant e Lyotard, reflexões acerca do Sublime". In Palíndromo n¹2. Julho/Dez. Florianópolis: UDESC.

WOLF, Norbert (2003). Friedrich. Colônia: Taschen.

Sites consultados:

itaucultural.org.br

https://pt.wikipedia.org/wiki/

Google Art Project 